\title{
Crystal and molecular structure and spectroscopic behavior of isotypic synthetic analogs of the oxalate minerals stepanovite and zhemchuzhnikovite
}

\author{
Oscar E. Piro ${ }^{1}$ Gustavo A. Echeverría ${ }^{1}$ Ana C. González-Baró ${ }^{2} \cdot$ Enrique J. Baran $^{2}$
}

Received: 26 August 2015 / Accepted: 16 December 2015 / Published online: 3 February 2016

(C) Springer-Verlag Berlin Heidelberg 2016

\begin{abstract}
The crystal structure of synthetic stepanovite, $\mathrm{Na}\left[\mathrm{Mg}\left(\mathrm{H}_{2} \mathrm{O}\right)_{6}\right]\left[\mathrm{Fe}\left(\mathrm{C}_{2} \mathrm{O}_{4}\right)_{3}\right] \cdot 3 \mathrm{H}_{2} \mathrm{O}$, and zhemchuzhnikovite, $\mathrm{Na}\left[\mathrm{Mg}\left(\mathrm{H}_{2} \mathrm{O}\right)_{6}\right]\left[\mathrm{Al}_{0.55} \mathrm{Fe}_{0.45}\left(\mathrm{C}_{2} \mathrm{O}_{4}\right)_{3}\right] \cdot 3 \mathrm{H}_{2} \mathrm{O}$, has been determined by single-crystal $\mathrm{X}$-ray diffraction methods. The compounds are isotypic to each other and to the previously reported $\mathrm{Na}\left[\mathrm{Mg}\left(\mathrm{H}_{2} \mathrm{O}\right)_{6}\right]\left[\mathrm{M}\left(\mathrm{C}_{2} \mathrm{O}_{4}\right)_{3}\right] \cdot 3 \mathrm{H}_{2} \mathrm{O} \quad(\mathrm{M}$ : $\mathrm{Cr}, \mathrm{Al})$. They crystallize in the trigonal $P 3 c 1$ space group with $Z=6$ molecules per unit cell and (hexagonal axes) $a=17.0483(4), c=12.4218(4) \AA$ for the iron compound, and $a=16.8852(5), c=12.5368(5) \AA$ for the $\mathrm{Al} / \mathrm{Fe}$ solid solution. Comparison of our crystallographic results with previous X-ray diffraction and chemical data of type stepanovite and zhemchuzhnikovite minerals provides compelling evidence that these natural materials possess the same crystal and molecular structure as their synthetic counterparts. It is shown that the originally reported unit cell for stepanovite represents a pronounced sub-cell and that the correct unit cell and space group are based on weak superstructure reflections. The infrared and Raman spectra of both synthetic analogs were also recorded and are briefly discussed.
\end{abstract}

Keywords Stepanovite $\cdot$ Zhemchuzhnikovite $\cdot$ Synthetic analogs $\cdot$ Crystal structure $\cdot$ Vibrational spectra

Enrique J. Baran

baran@quimica.unlp.edu.ar

1 Departamento de Física, Facultad de Ciencias Exactas, Universidad Nacional de La Plata and Institute IFLP (CONICET, CCT-La Plata), 1900 La Plata, Argentina

2 Centro de Química Inorgánica (CEQUINOR, CONICET/ UNLP), Facultad de Ciencias Exactas, Universidad Nacional de La Plata, C. C. 962, 1900 La Plata, Argentina

\section{Introduction}

Crystalline metal oxalates are widely distributed in nature and have been observed in rocks, soil, water bodies and among a variety of living organisms, including plants and animals. They form part of a group of relatively rare and scarce minerals which are usually classified as "organic minerals" (Strunz and Nickel 2001; Weiner and Dove 2003; Echigo and Kimata 2010; Baran 2014). Some of these crystalline oxalates are found in living organisms (in the form of the so-called biominerals), generated through some of the well-known biochemical and physiological strategies used for the formation of such biomineralisations (Fraústo da Silva and Williams 1991; Baran 1995; Weiner and Dove 2003; Monje and Baran 2004).

Carboxylate minerals, i.e., acetate, formate and oxalate minerals, constitute the largest family of organic minerals, and among them, the oxalates are the most abundant group, with eighteen different species reported so far (Echigo and Kimata 2010; Baran 2014), including three recently described sulfato-oxalato species (Peacor et al. 1999; Rouse et al. 2001) and one silico-aluminate-oxalato mineral (Chukanov et al. 2010).

Calcium oxalates are by far the most common oxalate minerals in all natural environments as well as in living organisms (Khan 1995; Baran and Monje 2009; Baran 2014), but different transition metal oxalates have also been found and described. Humboldtine, $\mathrm{Fe}\left(\mathrm{C}_{2} \mathrm{O}_{4}\right) \cdot 2 \mathrm{H}_{2} \mathrm{O}$, is a secondary mineral that occurs in lignite and pegmatites (Garavelli 1955a) and also associated with some iron oxides (Matioli et al. 1997), whereas the isotypic lindbergite, $\mathrm{Mn}\left(\mathrm{C}_{2} \mathrm{O}_{4}\right) \cdot 2 \mathrm{H}_{2} \mathrm{O}$, appears associated with different phosphate minerals, in manganese ore deposits or hydrothermal veins (Atencio et al. 2004). Besides, moolooite, 
$\mathrm{Cu}\left(\mathrm{C}_{2} \mathrm{O}_{4}\right) \cdot \mathrm{nH}_{2} \mathrm{O}$, was found associated with gypsum, silica, atacamite and other minerals (Clarke and Williams 1986), whereas wheatleyite, $\mathrm{Na}_{2}\left[\mathrm{Cu}\left(\mathrm{C}_{2} \mathrm{O}_{4}\right)_{2}\right] \cdot 2 \mathrm{H}_{2} \mathrm{O}$, was reported as associated with galena and sphalerite (Rouse et al. 1986).

Some more complex natural oxalates are stepanovite, $\mathrm{NaMg}\left[\mathrm{Fe}^{\mathrm{III}}\left(\mathrm{C}_{2} \mathrm{O}_{4}\right)_{3}\right] \cdot 8-9 \mathrm{H}_{2} \mathrm{O}$, which occurs in the form of yellowish-green granular aggregates in brown coal deposits in the estuary of the Lena river, polar Yacutia, Russia (Nefedov 1953; Fleischer 1955, 1964), and the related zhemchuzhnikovite, $\mathrm{NaMg}\left[\left(\mathrm{Al}, \mathrm{Fe}^{\mathrm{III}}\right)\left(\mathrm{C}_{2} \mathrm{O}_{4}\right)_{3}\right] \cdot 8 \mathrm{H}_{2} \mathrm{O}$, with $\mathrm{Al}: \mathrm{Fe}=1.22: 0.75$. This smoky green mineral was found in the same geographic region as stepanovite (Knipovich et al. 1963; Fleischer 1964), with which it appears associated, and was originally, based on a previous incomplete characterization (which indicated a Fe rich solid solution), tentatively considered by Fleischer (1962) to be either Albearing stepanovite or the Al-analog of stepanovite. The following trigonal unit-cell parameters, determined by Laue and rotation photographs, were given for stepanovite and zhemchuzhnikovite, respectively: $a=9.28, c=36.67$ $\AA$ (no uncertainties given) and $a=16.67(5), c=12.51(3)$ $\AA$. No powder diffraction patterns were given, and no possible space groups were suggested. Crystal structures of neither mineral have been reported yet. The current IMAapproved formula of stepanovite is $\mathrm{NaMgFe}^{3+}\left(\mathrm{C}_{2} \mathrm{O}_{4}\right)_{3} \cdot 8$ $9 \mathrm{H}_{2} \mathrm{O}$, while the formula of zhemchuzhnikovite is listed as $\mathrm{NaMgAl}\left(\mathrm{C}_{2} \mathrm{O}_{4}\right)_{3} \cdot 8 \mathrm{H}_{2} \mathrm{O}$.

A third related rare iron-oxalate mineral is minguzzite, $\mathrm{K}_{3}\left[\mathrm{Fe}^{\mathrm{III}}\left(\mathrm{C}_{2} \mathrm{O}_{3}\right)_{3}\right] \cdot 3 \mathrm{H}_{2} \mathrm{O}$, which was found associated with humboldtine and limonite at the iron deposit of Cap Calamita (Elba island, Italy) (Garavelli 1955b; Fleischer 1956).

The synthetic analogous complex to the mineral minguzzite is one of the best-known Fe(III) oxalate complexes, the tri-hydrated potassium tris(oxalato) ferrate(III), $\mathrm{K}_{3}\left[\mathrm{Fe}\left(\mathrm{C}_{2} \mathrm{O}_{4}\right)_{3}\right] \cdot 3 \mathrm{H}_{2} \mathrm{O}$. This complex can be easily obtained by different and well-established synthetic procedures (Baran 2014). The light green-colored crystals are photosensitive, the oxalate ligand being oxidized to $\mathrm{CO}_{2}$ with concomitant reduction in $\mathrm{Fe}(\mathrm{III})$ to $\mathrm{Fe}(\mathrm{II})$ (Krishnamurty and Harris 1961).

The crystal structure of $\mathrm{K}_{3}\left[\mathrm{Fe}\left(\mathrm{C}_{2} \mathrm{O}_{4}\right)_{3}\right] \cdot 3 \mathrm{H}_{2} \mathrm{O}$ was refined from single-crystal $\mathrm{X}$-ray diffractometer data some years ago (Junk 2005). It crystallizes in the monoclinic space group $P 2_{1} / c$ with $a=7.742(1), b=19.917(1)$, $c=10.346(1) \AA$ and $\beta=107.85(1)^{\circ}$ with $Z=4$. The $\left[\mathrm{Fe}\left(\mathrm{C}_{2} \mathrm{O}_{4}\right)_{3}\right]^{3-}$ anion presents a distorted $\mathrm{FeO}_{6}$ octahedral geometry with the three oxalate groups acting as bidentate ligands. The crystal structures of $\mathrm{K}_{3}\left[\mathrm{Cr}\left(\mathrm{C}_{2} \mathrm{O}_{4}\right)_{3}\right] \cdot 3 \mathrm{H}_{2} \mathrm{O}$ (van Niekerk and Schoening 1952; Taylor 1978) and of $\mathrm{K}_{3}\left[\mathrm{Al}\left(\mathrm{C}_{2} \mathrm{O}_{4}\right)_{3}\right] \cdot 3 \mathrm{H}_{2} \mathrm{O}$ (Taylor 1978) have also been determined, showing a close structural relation to that of $\mathrm{K}_{3}\left[\mathrm{Fe}\left(\mathrm{C}_{2} \mathrm{O}_{4}\right)_{3}\right] \cdot 3 \mathrm{H}_{2} \mathrm{O}$.
An anhydrous $\mathrm{K}_{3}\left[\mathrm{Fe}\left(\mathrm{C}_{2} \mathrm{O}_{4}\right)_{3}\right]$ could also be obtained and characterized very recently (Saritha et al. 2012). It crystallizes in the chiral cubic space group $P 4_{1} 32$ with $a=13.5970$ (2) $\AA$ and $Z=4$; the $\mathrm{Fe}$ (III) cation lies again in a distorted octahedral $\mathrm{FeO}_{6}$ environment.

Synthetic complexes analogous to the minerals stepanovite and zhemchuzhnikovite have never been described as such. Notwithstanding, a complex species of composition $\mathrm{NaMg}\left[\mathrm{Al}\left(\mathrm{C}_{2} \mathrm{O}_{4}\right)_{3}\right] \cdot 9 \mathrm{H}_{2} \mathrm{O}$ is well known, and has often been used as a host material for different spectroscopic studies, as part of the $\mathrm{Al}(\mathrm{III})$ can be easily replaced by other trivalent cations (Ti, V, Cr, Mn, Fe, Co) (Piper and Carlin 1961). Structural studies on any of these complexes have not been performed yet, although it was shown that $\mathrm{NaMg}\left[\mathrm{Al}\left(\mathrm{C}_{2} \mathrm{O}_{4}\right)_{3}\right] \cdot 9 \mathrm{H}_{2} \mathrm{O}$ belongs to the hexagonal system, but the space group could not be defined (Truchanowicz and Durski 1971) and it was also found that this complex is isostructural to the analogous $\mathrm{Cr}$ (III) complex (Truchanowicz 1974). Besides, it was shown that complex species of the type $\mathrm{NaMg}\left[\mathrm{Al}_{1-x} \mathrm{Fe}_{x}\left(\mathrm{C}_{2} \mathrm{O}_{4}\right)_{3}\right] \cdot 9 \mathrm{H}_{2} \mathrm{O}$ were also isostructural to $\mathrm{NaMg}\left[\mathrm{Cr}^{\mathrm{III}}\left(\mathrm{C}_{2} \mathrm{O}_{4}\right)_{3}\right] \cdot 9 \mathrm{H}_{2} \mathrm{O}$ (Lipkowski and Herbich 1975). This Cr(III) complex has usually been considered as a prototype for this family of oxalate complexes (Piper and Carlin 1960, 1961), and different attempts have been performed to determine its crystal structure. It was first obtained by Frossard (1956), and from chemical composition analysis, eight water molecules were reported. Furthermore, using photographic X-ray diffraction data, he determined the crystal system as trigonal, and from the observed extinction of reflections, the space group to be either $P-3 \mathrm{c} 1$ or its acentric counterpart $P 3 \mathrm{c} 1$. Some years later, Mortensen (1967) reported that the complex is in fact a nona- rather than a octahydrate, namely $\mathrm{NaMg}\left[\mathrm{Cr}\left(\mathrm{C}_{2} \mathrm{O}_{4}\right)_{3}\right] \cdot 9 \mathrm{H}_{2} \mathrm{O}$, and that it crystallizes in either the $P-3 \mathrm{c} 1$ or $P 3 c 1$ space group.

Finally, Suh et al. (1994) carried out a single-crystal $\mathrm{X}$-ray diffraction study where they report yet another hydrate, $\mathrm{NaMg}\left[\mathrm{Cr}\left(\mathrm{C}_{2} \mathrm{O}_{4}\right)_{3}\right] \cdot 10 \mathrm{H}_{2} \mathrm{O}$, and the same centrosymmetric $P-3 \mathrm{c} 1$ space group as above. These authors could not locate the water $\mathrm{H}$-atoms in their electrondensity maps. In a more recent work by Riesen and Rae (2008), where the crystal structure of the isomorphous $\mathrm{NaMg}\left[\mathrm{Al}\left(\mathrm{C}_{2} \mathrm{O}_{4}\right)_{3}\right] \cdot 9 \mathrm{H}_{2} \mathrm{O}$ compound is reported, the authors confirm the acentric $P 3 c 1$ space group and the nine water molecules, a conclusion that clearly extends to the chromium complex. Probably, because the authors employed in their X-ray experiments MoKa radiation that produces relatively small anomalous dispersion, they could not determine the absolute crystal structure. They were also unable to locate experimentally the water $\mathrm{H}$-atoms.

In a recent study, we finally removed the remaining uncertainties on the $\mathrm{NaMg}\left[\mathrm{Cr}\left(\mathrm{C}_{2} \mathrm{O}_{4}\right)_{3}\right] \cdot 9 \mathrm{H}_{2} \mathrm{O}$ solid by $\mathrm{X}$-ray crystallography, confirming the acentric $P 3 c 1$ space 
group, the nine water molecules, the site symmetry $C_{1}$ for the $\left[\mathrm{Cr}\left(\mathrm{C}_{2} \mathrm{O}_{4}\right)_{3}\right]^{3-}$ complex, and uncovering the absolute structure of the salt and its rich H-bonding network as revealed by experimental electron-density maps. Also, the crystal structure of the isotypic $\mathrm{NaMg}\left[\mathrm{Al}\left(\mathrm{C}_{2} \mathrm{O}_{4}\right)_{3}\right] \cdot 9 \mathrm{H}_{2} \mathrm{O}$ compound, i.e., conforming to an $\mathrm{Fe}$-free zhemchuzhnikovite, has been re-determined to have space group $\mathrm{P} 3 \mathrm{c} 1$ in the same study (Piro et al. 2015).

As it is highly probable that stepanovite and zhemchuzhnikovite are isotypic to each other, and to the also isotypic $\mathrm{NaMg}\left[\mathrm{Cr}\left(\mathrm{C}_{2} \mathrm{O}_{4}\right)_{3}\right] \cdot 9 \mathrm{H}_{2} \mathrm{O}$ and $\mathrm{NaMg}\left[\mathrm{Al}\left(\mathrm{C}_{2} \mathrm{O}_{4}\right)_{3}\right] \cdot 9 \mathrm{H}_{2} \mathrm{O}$ pair of complexes, we report here the synthesis of the two minerals and their complete structural and vibrational spectroscopic characterization.

\section{Materials and methods}

\section{Synthesis of the complexes}

All reagents, of analytical grade, were purchased commercially and used without purification. Elemental analysis (C, $\mathrm{H}$ and $\mathrm{N}$ ) was performed on a Carlo Erba model EA 1108 elemental analyzer.

The iron(III) complex, $\mathrm{NaMg}\left[\mathrm{Fe}\left(\mathrm{C}_{2} \mathrm{O}_{4}\right)_{3}\right] \cdot 9 \mathrm{H}_{2} \mathrm{O}$, was obtained by the reaction of an aqueous solution of $\mathrm{Na}_{3}\left[\mathrm{Fe}\left(\mathrm{C}_{2} \mathrm{O}_{4}\right)_{3}\right] \cdot 5 \mathrm{H}_{2} \mathrm{O}$ (prepared by reaction of a suspension of freshly precipitated $\mathrm{Fe}(\mathrm{OH})_{3}$ with an aqueous solution of $\mathrm{NaHC}_{2} \mathrm{O}_{4}$ ) with a great excess of $\mathrm{MgCl}_{2}$, in a similar way as described in detail by Frossard (1956) for the synthesis of the analogous $\mathrm{Cr}$ (III) compound. After a few days, well-formed bright green crystals of the complex begin to deposit. Analysis: Calculated for $\mathrm{C}_{6} \mathrm{H}_{18} \mathrm{FeMg}$ $\mathrm{NaO}_{21}$ : C, 13.60; H, 3.40. Found: C, 13.56; H, $3.45 \%$.

Crystals of the mixed cation $\mathrm{Al}(\mathrm{III}) / \mathrm{Fe}$ (III) complex, $\mathrm{NaMg}\left[\mathrm{Fe}_{1-x} \mathrm{Al}_{x}\left(\mathrm{C}_{2} \mathrm{O}_{4}\right)_{3}\right] \cdot 9 \mathrm{H}_{2} \mathrm{O}$, were obtained by the mixing of aqueous solutions of $\mathrm{NaMg}\left[\mathrm{Fe}\left(\mathrm{C}_{2} \mathrm{O}_{4}\right)_{3}\right] \cdot 9 \mathrm{H}_{2} \mathrm{O}$ and $\mathrm{NaMg}\left[\mathrm{Al}\left(\mathrm{C}_{2} \mathrm{O}_{4}\right)_{3}\right] \cdot 9 \mathrm{H}_{2} \mathrm{O}$, in different proportions. After some days, light green crystals of the complex were collected. The crystals of one of these reacting mixtures, which appeared particularly well formed, were selected for the following studies. Its elemental analysis, confirmed by the $\mathrm{X}$-ray diffraction experiments, gave the composition $\mathrm{NaMg}\left[\mathrm{Al}_{0.55} \mathrm{Fe}_{0.45}\left(\mathrm{C}_{2} \mathrm{O}_{4}\right)_{3}\right] \cdot 9 \mathrm{H}_{2} \mathrm{O}$. Analysis: Calculated for $\mathrm{C}_{6} \mathrm{H}_{18} \mathrm{Fe}_{0.45} \mathrm{Al}_{0.55} \mathrm{MgNaO}_{21}: \mathrm{C}, 14.02 ; \mathrm{H}, 3.50$. Found: $\mathrm{C}$, $13.97 ; \mathrm{H}, 3.54 \%$. The crystals show a pronounced cleavage parallel to (0001).

The pure $\mathrm{Al}(\mathrm{III})$ complex, $\mathrm{NaMg}\left[\mathrm{Al}\left(\mathrm{C}_{2} \mathrm{O}_{4}\right)_{3}\right] \cdot 9 \mathrm{H}_{2} \mathrm{O}$, necessary for this synthesis was obtained by reaction of stoichiometric amounts of $\mathrm{Al}_{2}\left(\mathrm{SO}_{4}\right)_{3}, \mathrm{Ba}(\mathrm{OH})_{2}, \mathrm{NaOH}, \mathrm{MgO}$ and $\mathrm{H}_{2} \mathrm{C}_{2} \mathrm{O}_{4} \cdot 2 \mathrm{H}_{2} \mathrm{O}$ in aqueous solution, as described earlier (Piper and Carlin 1961; Piro et al. 2015).

\section{X-ray crystallographic studies}

The measurements were taken on an Oxford Xcalibur Eos Gemini CCD single-crystal diffractometer with graphite-monochromated $\operatorname{MoK} \alpha(\lambda=0.71073 \AA)$ and $\mathrm{CuK \alpha}$ $(\lambda=1.54184 \AA)$ radiation. $\mathrm{X}$-ray diffraction intensities were collected ( $\omega$-scans with $\vartheta$ - and $\kappa$-offsets), integrated and scaled with the CrysAlisPro (2014) suite of programs. The unit-cell parameters were obtained by least squares refinement (based on the angular settings for all collected reflections with intensities larger than seven times the standard deviation of measurement errors) using CrysAlisPro. Data were corrected empirically for absorption employing the multi-scan method implemented in CrysAlisPro.

The $\mathrm{Na}\left[\mathrm{Mg}\left(\mathrm{H}_{2} \mathrm{O}\right)_{6}\right]\left[\mathrm{Fe}\left(\mathrm{C}_{2} \mathrm{O}_{4}\right)_{3}\right] \cdot 3 \mathrm{H}_{2} \mathrm{O}$ complex and the $\mathrm{Na}\left[\mathrm{Mg}\left(\mathrm{H}_{2} \mathrm{O}\right)_{6}\right]\left[\mathrm{Al}_{0.55} \mathrm{Fe}_{0.45}\left(\mathrm{C}_{2} \mathrm{O}_{4}\right)_{3}\right] \cdot 3 \mathrm{H}_{2} \mathrm{O}$ metal solution are isotypic to each other and to the previously reported $\mathrm{Na}\left[\mathrm{Mg}\left(\mathrm{H}_{2} \mathrm{O}\right)_{6}\right]\left[\mathrm{M}\left(\mathrm{C}_{2} \mathrm{O}_{4}\right)_{3}\right] \cdot 3 \mathrm{H}_{2} \mathrm{O}(\mathrm{M}$ : $\mathrm{Cr}$, Al) isotypic pair (Riesen and Rae 2008; Piro et al. 2015). In fact, an initial structural model assuming the same $P 3 c 1$ space group and positions of non-H-atoms as in the chromium analog crystal with the identity of the transition metal changed to either iron or a mixture of iron and aluminum lead to smooth convergence of the respective structural parameters.

The structure of $\mathrm{Na}\left[\mathrm{Mg}\left(\mathrm{H}_{2} \mathrm{O}\right)_{6}\right]\left[\mathrm{Fe}\left(\mathrm{C}_{2} \mathrm{O}_{4}\right)_{3}\right] \cdot 3 \mathrm{H}_{2} \mathrm{O}$ was first refined with the SHELXL (version 2014/7) program of the SHELX package (Sheldrick 2008) using a MoKa dataset. Despite the presence of a relatively heavy atom (Fe), the crystal was re-measured with $\mathrm{Cu} K \alpha$ radiation to enhance the atomic anomalous dispersion of the pseudocentrosymmetric solid and thus to improve the reliability of its absolute structure determination.

For the same reason, the structure of the synthetic zhemchuzhnikovite with $\mathrm{Al}: \mathrm{Fe}=0.55: 0.45$ was refined against $\mathrm{Cu} K \alpha$ diffraction data. During the refinement, aluminum and iron atoms were constrained to occupy the same atomic site [with a total (Al, Fe) occupancy of 1.00] and to have identical anisotropic displacement parameters.

All water $\mathrm{H}$-atoms in synthetic stepanovite were located among the first 18 most intense peaks of a difference Fourier map. The $\mathrm{H}$-atoms in synthetic zhemchuzhnikovite were less defined, and all of them appeared at approximate locations among the first 25 peaks of the corresponding map. The hydrogen atoms were refined at their found positions with $\mathrm{Ow}-\mathrm{H}$ and $\mathrm{H} \cdots \mathrm{H}$ distances restrained to target values of 0.86(1) and 1.36(1) $\AA$ and isotropic displacement parameters equal to 1.5 times the one of the corresponding water oxygen. Crystal data, data collection procedure and refinement results for both compounds are summarized in Table 1.

To rule out other space groups compatible with the $\mathrm{X}$-ray extinctions and intensities statistics (like $P-3 c 1$ ), 
Table 1 Crystal data and structure refinement results for isomorphic synthetic stepanovite and zhemchuzhnikovite minerals

\begin{tabular}{|c|c|c|}
\hline & Stepanovite & Zhemchuzhnikovite \\
\hline Empirical formula & $\mathrm{C}_{6} \mathrm{H}_{18} \mathrm{FeMgNaO}_{21}$ & $\mathrm{C}_{6} \mathrm{H}_{18} \mathrm{Al}_{0.55} \mathrm{Fe}_{0.45} \mathrm{MgNaO}_{21}$ \\
\hline Formula weight & 529.35 & 513.39 \\
\hline Temperature $(\mathrm{K})$ & $297(2)$ & $297(2)$ \\
\hline Crystal shape/color & Plate/yellowish-green & Prism/yellowish-green \\
\hline Crystal size $\left(\mathrm{mm}^{3}\right)$ & $0.374 \times 0.313 \times 0.133$ & $0.177 \times 0.131 \times 0.113$ \\
\hline Wavelength $(\AA)$ & 0.7103 & 1.54184 \\
\hline Crystal system & Trigonal & Trigonal \\
\hline Space group & $P 3 c 1$ & $P 3 c 1$ \\
\hline \multicolumn{3}{|l|}{ Lattice parameters } \\
\hline$a(\AA)$ & $17.0483(4)$ & $16.8852(5)$ \\
\hline$c(\AA)$ & $12.4218(4)$ & $12.5368(5)$ \\
\hline Volume $\left(\AA^{3}\right)$ & $3126.7(1)$ & $3095.5(2)$ \\
\hline$Z$ & 6 & 6 \\
\hline$D_{\text {calc }}\left(\mathrm{g} / \mathrm{cm}^{3}\right)$ & 1.687 & 1.652 \\
\hline Absorption coeff. $\left(\mathrm{mm}^{-1}\right)$ & 0.870 & 4.541 \\
\hline $\mathrm{F}(000)$ & 1626 & 1583 \\
\hline$\theta$-range data collect. $\left(^{\circ}\right)$ & $2.90-27.00$ & $5.24-70.99$ \\
\hline Index ranges & $-19 \leq \mathrm{h} \leq 21,-21 \leq \mathrm{k} \leq 14,-15 \leq 1 \leq 15$ & $-19 \leq \mathrm{h} \leq 13,-15 \leq \mathrm{k} \leq 20,-15 \leq \mathrm{l} \leq 13$ \\
\hline Reflections collected & 9402 & 8323 \\
\hline Independent reflections & $3768[\mathrm{R}(\mathrm{int})=0.0253]$ & $3189[\mathrm{R}(\mathrm{int})=0.0233]$ \\
\hline Observed reflect. $[I>2 \sigma(\mathrm{I})]$ & 3126 & 2673 \\
\hline Refinement method & Full-matrix least sq. on $F^{2}$ & Full-matrix least sq. on $F^{2}$ \\
\hline Data/restraints/param. & $3768 / 28 / 325$ & $3189 / 28 / 327$ \\
\hline Goodness-of-fit on $F^{2}$ & 1.034 & 1.068 \\
\hline Final $\mathrm{R}$ indices $[I>2 \sigma(\mathrm{I})]$ & $\mathrm{R} 1=0.0352, \mathrm{wR} 2=0.0916$ & $\mathrm{R} 1=0.0405, \mathrm{wR} 2=0.1129$ \\
\hline $\mathrm{R}$ indices (all data) & $\mathrm{R} 1=0.0468, \mathrm{wR} 2=0.1001$ & $\mathrm{R} 1=0.0482, \mathrm{wR} 2=0.1211$ \\
\hline Flack parameter & $0.133(9)(\mathrm{CuK} \alpha$ radiation $)$ & $0.36(1)$ : racemic twin \\
\hline Larg. diff. peak and hole $\left(\mathrm{e} \AA^{-3}\right.$ ) & 0.26 and -0.46 & 0.60 and -0.24 \\
\hline
\end{tabular}

we resorted to an independent procedure called 'intrinsic phasing' implemented in the SHELXT program (Sheldrick 2015). Intrinsic phasing departs from standard structure determination procedures where normally the space group is determined first and the crystal structure afterward. Now, with the only prior knowledge of the Laue group and the atom species present in the solid:

1. The X-ray diffraction dataset is expanded to the $P 1$ space group where the structure is solved from an initial trial constellation of peaks provided by Patterson superposition methods. This is followed by dualspace recycling to obtain optimal electron density and phases.

2. The phases are first subjected to a centrosymmetric test, and a measure of the phase error $\left(\alpha_{0}\right)$ is calculated. This should be small for a constellation of atoms that possesses an inversion center.
3. The phases are then employed in a full search for the correct space group and the translation necessary to refer the electron density to the proper unit-cell origin.

4. The phases are then averaged in every possible space group compatible with the known Laue group and used to calculate improved maps.

5. The integrated electron density around the peaks of the maps is assigned to the assumed atomic species, and thus, a chemical formula is proposed.

6. The correct space group and structure solution are selected among the trials on the basis of several figures of merit, including the standard agreement $R 1$-factor, $R_{\text {weak }}$ (average of calculated $E_{\text {calc }}^{2}$ for the $10 \%$ of unique reflections with the smallest observed normalized structure factors $E_{\mathrm{obs}}$ ) and the phase error $(\alpha)$, all of which should be the smallest for the right choice. 
Table 2 Candidate space groups with the best figures of merit obtained with SHELXT (Sheldrick 2015) from the two centrosymmetric and five non-centrosymmetric trigonal space groups with the

\begin{tabular}{|c|c|c|c|c|c|c|}
\hline \multirow[t]{2}{*}{ SG } & \multicolumn{3}{|c|}{$\mathrm{NaMg}\left[\mathrm{Fe}\left(\mathrm{C}_{2} \mathrm{O}_{4}\right)_{3}\right] \cdot 9 \mathrm{H}_{2} \mathrm{O}$} & \multicolumn{3}{|c|}{$\mathrm{NaMg}\left[\mathrm{Al}_{0.55} \mathrm{Fe}_{0.45}\left(\mathrm{C}_{2} \mathrm{O}_{4}\right)_{3}\right] \cdot 9 \mathrm{H}_{2} \mathrm{O}$} \\
\hline & $\mathrm{R} 1$ & R (weak) & $\alpha$ & $\mathrm{R} 1$ & R (weak) & $\alpha$ \\
\hline$P-3 c 1$ & 0.181 & 0.014 & 0.055 & 0.194 & 0.004 & 0.052 \\
\hline$P 3 c 1$ & 0.123 & 0.003 & 0.018 & 0.118 & 0.001 & 0.016 \\
\hline$P 321$ & 0.175 & 0.003 & 0.052 & 0.184 & 0.002 & 0.051 \\
\hline
\end{tabular}

Laue group $P-3 m 1\left(D_{3 d}\right)$ of isomorphic $\mathrm{NaMg}\left[\mathrm{Fe}\left(\mathrm{C}_{2} \mathrm{O}_{4}\right)_{3}\right] \cdot 9 \mathrm{H}_{2} \mathrm{O}$ and $\mathrm{NaMg}\left[\mathrm{Al}_{0.55} \mathrm{Fe}_{0.45}\left(\mathrm{C}_{2} \mathrm{O}_{4}\right)_{3}\right] \cdot 9 \mathrm{H}_{2} \mathrm{O}$
The results of these procedures applied to the X-ray diffraction data of isotypic $\mathrm{Na}\left[\mathrm{Mg}\left(\mathrm{H}_{2} \mathrm{O}\right)_{6}\right]\left[\mathrm{M}\left(\mathrm{C}_{2} \mathrm{O}_{4}\right)_{3}\right] \cdot 3 \mathrm{H}_{2} \mathrm{O}$ crystals with $\mathrm{M}=\mathrm{Fe}$ or $\mathrm{Al}_{0.55} / \mathrm{Fe}_{0.45}$ mixture, assuming that the Laue group $P-3 m 1\left(D_{3 d}\right)$ and the presence of Fe, $\mathrm{Al}, \mathrm{Mg}, \mathrm{Na}, \mathrm{O}$ and $\mathrm{C}$ atomic species in the solid are shown in Table 2. From this table, it can be appreciated that the procedure clearly selects the acentric space group $P 3 c 1$ as having the best indicators. The procedure also shows the pseudo-inversion-related character of the atoms' constellation, here quantified by small values of the phase error $\alpha_{0}$ (equal to 0.112 for $\mathrm{M}=\mathrm{Fe}$ and to 0.105 for $\mathrm{Al}_{0.55} / \mathrm{Fe}_{0.45}$ solid solution), which could have led to wrongly adopt the centric $P-3 c 1$ space group.

Interestingly, in the case of synthetic stepanovite the program determines for $P 3 c 1$ the chemical (non- $\mathrm{H}$ ) formula $\mathrm{C}_{11} \mathrm{O}_{16} \mathrm{FeNaMg}$ rather than the correct one, namely $\mathrm{C}_{6} \mathrm{O}_{21} \mathrm{FeNaMg}$, because it miss-assigns five oxygen atoms as carbons.

For the synthetic zhemchuzhnikovite, however, the SHELXT formula is unreliable as the program derives it based on a preliminary trial structure (not fully refined) assuming an occupationally ordered crystal, which is not the case of the zhemchuzhnikovite $\mathrm{Al} / \mathrm{Fe}$ solid solution.

\section{Spectroscopic measurements}

The infrared spectra in the frequency range between 4000 and $400 \mathrm{~cm}^{-1}$ were recorded as $\mathrm{KBr}$ pellets with a FTIRBruker-EQUINOX-55 spectrophotometer. Raman spectra were obtained in the same spectral range with a Thermo Scientific DXR Raman microscope, using the $532 \mathrm{~nm}$ line of a Thermo Scientific solid-state laser diode pump for excitation.

\section{Results and discussion}

\section{Crystal structures}

The synthetic minerals are isotypic to each other and to the previously reported $\mathrm{Na}\left[\mathrm{Mg}\left(\mathrm{H}_{2} \mathrm{O}\right)_{6}\right]\left[\mathrm{M}\left(\mathrm{C}_{2} \mathrm{O}_{4}\right)_{3}\right] \cdot 3 \mathrm{H}_{2} \mathrm{O}$
$(\mathrm{M}=\mathrm{Cr}, \mathrm{Al})$ isotypic pair (Riesen and Rae 2008; Piro et al. 2015). Figure 1 shows an ORTEP drawing (Farrugia 1997) of synthetic stepanovite, and corresponding bond distances and angles around the metals are in Tables 3 (stepanovite) and 4 (zhemchuzhnikovite).

The metal (M) and sodium ions are at crystal general positions, in octahedral environments coordinated to three oxalate molecules acting as bidentate ligands through the oxygen atoms of their opposite carboxylic groups in a propeller-like conformation where $\mathrm{M}\left(\mathrm{C}_{2} \mathrm{O}_{4}\right)_{3}$ and $\mathrm{Na}\left(\mathrm{C}_{2} \mathrm{O}_{4}\right)_{3}$ molecular fragments present opposite handedness. $\mathrm{M}-\mathrm{O}$ bond lengths are in the range from 2.008(3) to 2.030(4) $\AA$ for $\mathrm{M}=\mathrm{Fe}$ in stepanovite and in the 1.948(4)1.971(4) $\AA$ range for Fe-bearing zhemchuzhnikovite with $\mathrm{Al}: \mathrm{Fe}=0.55: 045$. Na-O bond distances are in the 2.357(5)-2.386(5) $\AA$ and 2.313(6)-2.420(4) $\AA$ intervals for stepanovite and zhemchuzhnikovite, respectively. Due to the threefold axes in the structure, these metal ions are in a honeycomb-like layered arrangement formed by alternating metal and sodium atoms linked through sharing oxalate ligands (see Fig. 1).

There are three different $\mathrm{Mg}(\mathrm{II})$ ions positioned in three special sites of $C_{3}$ symmetry in space group $P 3 c 1$ (Wyckoff $a, b$ and $c$ sites), and they are located in the honeycomb plane. $\mathrm{The} \mathrm{Mg}(\mathrm{II})$ ions are octahedrally coordinated to water molecules through their oxygen lone pairs. $\mathrm{Mg}$-Ow distances are in the range from 2.055(4) to 2.075(4) $\AA$ in stepanovite and from 2.048(4) to 2.089(4) $\AA$ in zhemchuzhnikovite. The three $\left[\mathrm{Mg}\left(\mathrm{H}_{2} \mathrm{O}\right)_{6}\right]^{2+}$ hydrated ions fill the honeycomb holes hence giving rise to an electrically neutral layered structure of about $2.4 \AA$ in thickness (measured between surface non-H-atoms) or about $5.5 \AA$ considering van der Waals layer contours. These layers can be conveniently described as $\mathrm{Na}\left[\mathrm{Mg}\left(\mathrm{H}_{2} \mathrm{O}\right)_{6}\right]\left[\mathrm{M}\left(\mathrm{C}_{2} \mathrm{O}_{4}\right)_{3}\right]$ and the whole crystal as $\mathrm{Na}\left[\mathrm{Mg}\left(\mathrm{H}_{2} \mathrm{O}\right)_{6}\right]\left[\mathrm{M}\left(\mathrm{C}_{2} \mathrm{O}_{4}\right)_{3}\right] \cdot 3 \mathrm{H}_{2} \mathrm{O}$. Neighboring layers are symmetry related to each other through the $c$-glide plane, and therefore, they are $c / 2$ apart [6.2109(3) $\AA$ for $\mathrm{M}=\mathrm{Fe}$ and 6.2684(4) $\AA$ for $\mathrm{M}=\mathrm{Al}_{0.55} \mathrm{Fe}_{0.45}$ solution]. The layers are weakly bonded to each other mainly through $\mathrm{H}$-bonding bridges involving the remaining three water molecules (see Fig. 1 and text below). This explains the easy-cleavage 
plane parallel to (0001) observed in both synthetic and natural zhemchuzhnikovite (Fleischer 1964). Interestingly, as a consequence of the highly symmetric honeycomb structure and the above-mentioned crystallographic $c$-glide plane, all atoms in the layer, except for the water molecules and the interchange of $\mathrm{M}$ and sodium atoms, are nearly stacked up along the $c$-axis giving rise to a quasi-periodicity of $c / 2$ repeatability. This reflects itself in a modulated X-ray diffraction pattern where one observes on reciprocal hkil layers perpendicular to $c^{*}$-axis relatively weak average intensities for $l=$ odd layers as compared with the ones for $l=$ even.

The nine water molecules per chemical formula can be split into two sets. One of them contains six coordinatedto-magnesium water molecules $(\mathrm{O} 1 \mathrm{w}-\mathrm{O} 6 \mathrm{w}$ in Fig. 1) which in turn can be arranged into three subsets with two molecules each: $(\mathrm{O} 1 \mathrm{w}, \mathrm{O} 2 \mathrm{w}),(\mathrm{O} 3 \mathrm{w}, \mathrm{O} 4 \mathrm{w})$ and $(\mathrm{O} 5 \mathrm{w}$, O6w) coordinated, respectively, to the three independent $\mathrm{Mg}$ (II) ions at the three $C_{3}$ sites giving rise to the abovementioned $\left[\mathrm{Mg}\left(\mathrm{H}_{2} \mathrm{O}\right)_{6}\right]^{2+}$ hydrated ions. The other set contains the remaining three molecules which act as only weakly hydrogen-bonded water molecules $(\mathrm{O} 7 \mathrm{w}-\mathrm{O} 9 \mathrm{w})$. They are sandwiched between neighboring $\mathrm{Na}\left[\mathrm{Mg}\left(\mathrm{H}_{2} \mathrm{O}\right)_{6}\right]$ $\left[\mathrm{M}\left(\mathrm{C}_{2} \mathrm{O}_{4}\right)_{3}\right]$ crystal layers bridging them through medium to strong H-bonds. In fact, all three water molecules act as $\mathrm{H}$-donors in $\mathrm{O}(\mathrm{ox}) \cdots \mathrm{H}-\mathrm{Ow}-\mathrm{H} \cdots \mathrm{O}(\mathrm{ox})$ bridges with oxalate oxygen atoms [Ow... $\mathrm{O}(\mathrm{ox})$ distances in the $2.721-2.796 \AA$ range for stepanovite and in the 2.723-2.798 $\AA$ interval for zhemchuzhnikovite] and also as $\mathrm{H}$-acceptors in $\mathrm{Ow}-$ $\mathrm{H} \cdots \mathrm{Ow} \cdots \mathrm{H}-\mathrm{Ow}$ bridges with coordinated-to-magnesium water molecules [Ow... Ow lengths from 2.727 to $2.754 \AA$ for stepanovite and from 2.713 to $2.757 \AA$ for zhemchuzhnikovite]. The H-bonding structure is further detailed in Tables 5 (stepanovite) and 6 (zhemchuzhnikovite).

Supplementary crystallographic data for this paper are deposited at the Cambridge Crystallographic Data Centre under the numbers CCDC 1417409 (synthetic stepanovite) and CCDC 1417410 (synthetic zhemchuzhnikovite). These data can be obtained free of charge via www.ccdc.cam. ac-uk/data-request/cif.

\section{Synthetic versus natural stepanovite}

\section{Geometric relationship between their hexagonal lattices}

Table 7 compares the crystallographic data of synthetic stepanovite with reported crystal and chemical information for the natural mineral. These data strongly suggest the existence of a close geometrical relationship between the unit cell determined for the synthetic analog and that reported for the naturally occurring crystals. This is shown in Fig. 2.
The relationship between unit-cell vectors of natural (s) stepanovite and the synthetic analog is:

$$
\left[\begin{array}{l}
\vec{a}_{S} \\
\vec{b}_{S} \\
\vec{c}_{S}
\end{array}\right]=\left[\begin{array}{ccc}
2 / 3 & 1 / 3 & 0 \\
-1 / 3 & 1 / 3 & 0 \\
0 & 0 & 3
\end{array}\right]\left[\begin{array}{l}
\vec{a} \\
\vec{b} \\
\vec{c}
\end{array}\right],
$$

and the corresponding relationship between the Miller indices of Bragg reflections is,

$\left[\begin{array}{l}h_{S} \\ k_{S} \\ l_{S}\end{array}\right]=\left[\begin{array}{ccc}2 / 3 & 1 / 3 & 0 \\ -1 / 3 & 1 / 3 & 0 \\ 0 & 0 & 3\end{array}\right]\left[\begin{array}{l}h \\ k \\ l\end{array}\right]$.

From Table 7, it can be clearly appreciated that the above geometric relationships between the two cells are closely satisfied. In fact,

$$
\begin{aligned}
a_{S} \cong a / \sqrt{3} & =9.8428(2) \AA, \\
c_{S} \cong 3 c & =37.265(1) \AA .
\end{aligned}
$$

The possibility that the previously reported unit-cell determination of natural stepanovite (determined by film methods (cf. Fleischer 1964) may have yielded the incorrect smaller unit cell in the crystal $a b$-plane embedded in the larger correct one can be envisaged by the complete crystal structure solution of synthetic stepanovite mineral reported here. In fact, the projection of the solid down the $c$-axis shown in Fig. 1 clearly indicates that the existence of a quasi-periodicity defined by the unit-cell axes transformation of Eq. (1) and whose corresponding unit cell is included in the figure.

As a consequence of this structure-superstructure relationship in the $a b$-plane, it is to be expected that weak lowresolution $(h k i O)$ reflections of the synthetic analog give rise to non-integer Miller indices of the sub-cell, according to Eq. (2). This can be appreciated in the (hkiO) diffraction data of Fig. 3 which hence may explain why the early $\mathrm{X}$-ray diffraction studies have missed the correct superstructure cell.

No superstructure reflections associated with the $c_{S} \cong 3 c$ periodicity reported in the literature for the natural stepanovite were observed in the diffraction data of our synthetic material, and we shall assume here the substructure cell to have $c_{S} \cong c$. We then referred our X-ray diffraction data to the above sub-cell to find that the symmetry of intensities now obey the trigonal $P-3\left(S_{6}\right)$ Laue subgroup of the correct superstructure $P-3 m 1\left(D_{3 d}\right)$ Laue group. Next we tried to solve the substructure with SHELXT (Sheldrick 2015) obtaining basically the same non-water superstructure architecture where the metals are at special positions of $C_{3}$ symmetry of space group $P-3$ (Wyckoff $d$ sites for iron and sodium and $c$ site for magnesium). Since the water molecules are mainly responsible for breaking the sub-cell periodicity (see embedded sub-cell in Fig. 1), as expected 

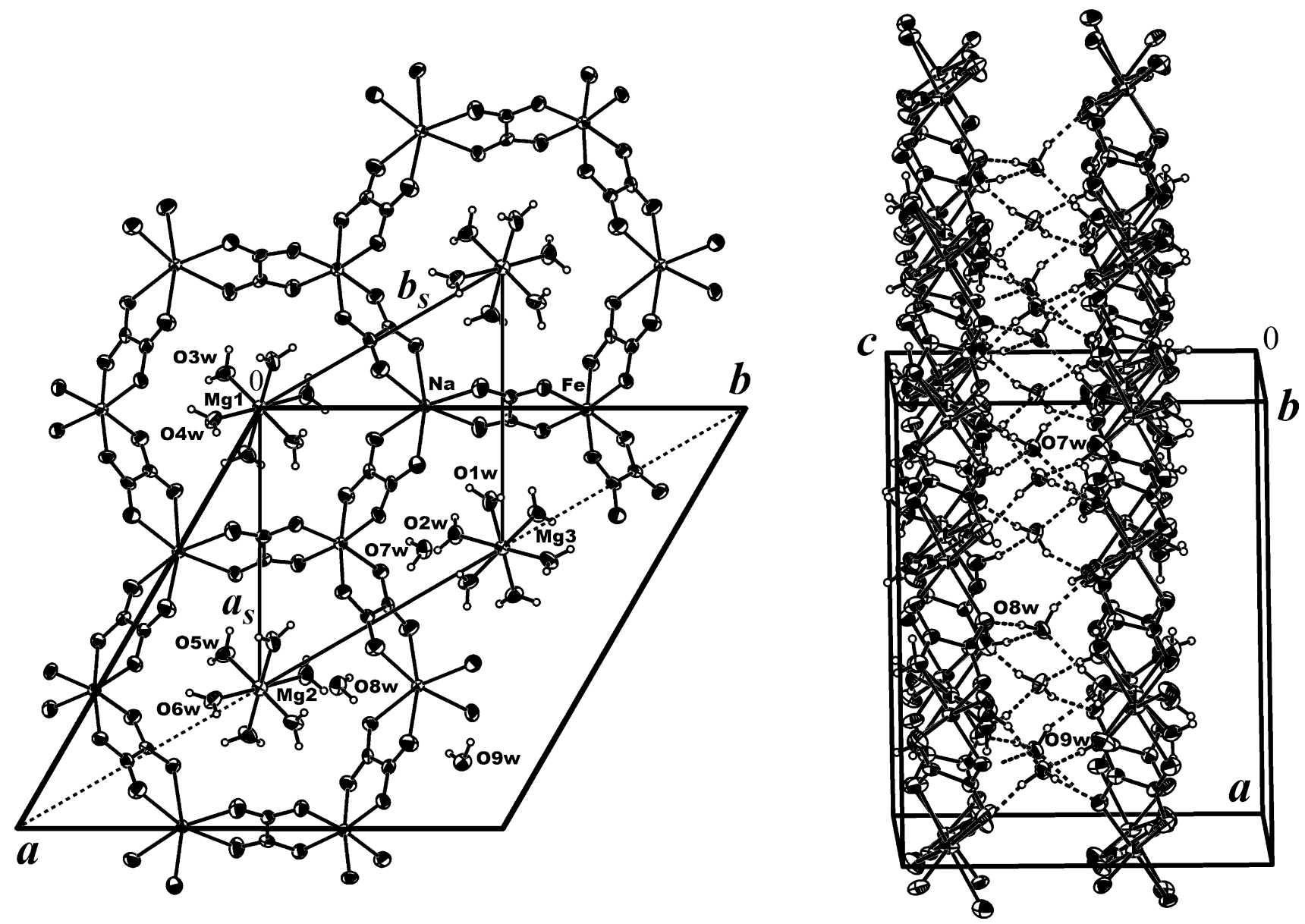

Fig. 1 Left: view of ORTEP plot of synthetic stepanovite, $\mathrm{Na}\left[\mathrm{Mg}\left(\mathrm{H}_{2} \mathrm{O}\right)_{6}\right]\left[\mathrm{Fe}\left(\mathrm{C}_{2} \mathrm{O}_{4}\right)_{3}\right] \cdot 3 \mathrm{H}_{2} \mathrm{O}$, down the trigonal axis, showing the displacement ellipsoids at the $50 \%$ probability level. The crystallographic $c$-glide plane relating neighboring $\mathrm{Na}\left[\mathrm{Mg}\left(\mathrm{H}_{2} \mathrm{O}\right)_{6}\right]$ $\left[\mathrm{Fe}\left(\mathrm{C}_{2} \mathrm{O}_{4}\right)_{3}\right]$ layers along the $c$-axis is shown by dotted lines. The trig-

they are ill defined in the electron-density map which therefore indicates a wrong hydrate, namely $\mathrm{Na}\left[\mathrm{Mg}\left(\mathrm{H}_{2} \mathrm{O}\right)_{6}\right]$ $\left[\mathrm{Fe}\left(\mathrm{C}_{2} \mathrm{O}_{4}\right)_{3}\right] \cdot 6 \mathrm{H}_{2} \mathrm{O}$, a clear indication of how a wrong space group leads to incorrect water counting in these systems.

Early miss-assignments of unit-cell dimensions in other isotypic synthetic crystal, namely $\mathrm{Na}\left[\mathrm{Mg}\left(\mathrm{H}_{2} \mathrm{O}\right)_{6}\right]$ $\left[\mathrm{Cr}\left(\mathrm{C}_{2} \mathrm{O}_{4}\right)_{3}\right] \cdot 3 \mathrm{H}_{2} \mathrm{O}$, have been published (Frossard 1956). This is probably due in part to the above substructure quasiperiodicity and also to relatively weak intensity of old $\mathrm{X}$-ray sources, the low sensitivity of photographic recordings and incomplete diffraction datasets. In fact, Frossard (1956) reported for the chromium complex to crystallize in the trigonal system with unit-cell parameters $a=9.78(4)$ $\AA, c=12.5(2) \AA$, and $Z=2$, closely corresponding to the modern correct values for the sub-cell, namely: $a / \sqrt{3}=9.7939(2) \AA, c=12.5247(3) \AA$, and $Z / 3=2$ (Piro et al. 2015). onal $\left(\boldsymbol{a}_{\boldsymbol{S}}, \boldsymbol{b}_{S}\right)$ sub-cell is shown by thin lines embedded in the correct $(a, b)$ cell. Right: view perpendicular to the trigonal axis. The crystal layered arrangement is seen edge-on. The H-bonding arrangement linking neighboring layers through bridging water molecules is indicated by dashed lines

\section{Synthetic versus natural zhemchuzhnikovite}

Table 8 compares the crystallographic data of synthetic zhemchuzhnikovite with reported crystal and chemical information for the natural mineral. From this table, it can be appreciated that a major difference lies with the water counting. The determination of the correct space group and the related problem of the exact water content in these systems proved to be elusive, as commented in the introduction of this paper, and as also mentioned, the uncertainties concerning the space group and water content in the isomorphic chromium(III) complex were not settled definitively until very recently (Piro et al. 2015).

From the above comparisons of our crystallographic results with chemical information and early X-ray diffraction data for stepanovite and zhemchuzhnikovite reported in the literature, it can be safely concluded that these 
Table 3 Bond lengths $[\AA ̊]$ and angles $\left[{ }^{\circ}\right]$ around the metals in stepanovite

\begin{tabular}{|c|c|c|c|}
\hline $\mathrm{Fe}-\mathrm{O}(11)$ & $2.014(4)$ & $\mathrm{O}(22)-\mathrm{Fe}-\mathrm{O}(32)$ & $92.7(1)$ \\
\hline $\mathrm{Fe}-\mathrm{O}(12)$ & $2.005(4)$ & $\mathrm{O}(21)-\mathrm{Fe}-\mathrm{O}(32)$ & $93.9(2)$ \\
\hline $\mathrm{Fe}-\mathrm{O}(21)$ & $2.015(4)$ & & \\
\hline $\mathrm{Fe}-\mathrm{O}(22)$ & $2.013(4)$ & $\mathrm{O}(34)-\mathrm{Na}-\mathrm{O}(24) \# 3$ & $103.1(2)$ \\
\hline $\mathrm{Fe}-\mathrm{O}(31)$ & $2.008(3)$ & $\mathrm{O}(34)-\mathrm{Na}-\mathrm{O}(33)$ & 71.1(1) \\
\hline \multirow[t]{2}{*}{$\mathrm{Fe}-\mathrm{O}(32)$} & $2.030(4)$ & $\mathrm{O}(24) \# 3-\mathrm{Na}-\mathrm{O}(33)$ & $165.6(2)$ \\
\hline & & $\mathrm{O}(34)-\mathrm{Na}-\mathrm{O}(23) \# 3$ & $93.0(2)$ \\
\hline $\mathrm{Na}-\mathrm{O}(33)$ & $2.362(5)$ & $\mathrm{O}(24) \# 3-\mathrm{Na}-\mathrm{O}(23) \# 3$ & $71.9(1)$ \\
\hline $\mathrm{Na}-\mathrm{O}(34)$ & $2.357(5)$ & $\mathrm{O}(33)-\mathrm{Na}-\mathrm{O}(23) \# 3$ & $94.9(2)$ \\
\hline $\mathrm{Na}-\mathrm{O}(24) \# 3$ & $2.376(4)$ & $\mathrm{O}(34)-\mathrm{Na}-\mathrm{O}(13) \# 4$ & $99.9(2)$ \\
\hline $\mathrm{Na}-\mathrm{O}(23) \# 3$ & $2.371(5)$ & $\mathrm{O}(24) \# 3-\mathrm{Na}-\mathrm{O}(13) \# 4$ & $98.2(2)$ \\
\hline $\mathrm{Na}-\mathrm{O}(13) \# 4$ & $2.386(5)$ & $\mathrm{O}(33)-\mathrm{Na}-\mathrm{O}(13) \# 4$ & $95.9(1)$ \\
\hline \multirow[t]{2}{*}{$\mathrm{Na}-\mathrm{O}(14) \# 4$} & $2.367(6)$ & $\mathrm{O}(23) \# 3-\mathrm{Na}-\mathrm{O}(13) \# 4$ & $165.4(1)$ \\
\hline & & $\mathrm{O}(34)-\mathrm{Na}-\mathrm{O}(14) \# 4$ & $164.9(1)$ \\
\hline $\mathrm{Mg}(1)-\mathrm{O}(3 \mathrm{~W})$ & $2.064(4)$ & $\mathrm{O}(24) \# 3-\mathrm{Na}-\mathrm{O}(14) \# 4$ & $89.9(1)$ \\
\hline \multirow[t]{2}{*}{$\mathrm{Mg}(1)-\mathrm{O}(4 \mathrm{~W})$} & $2.068(4)$ & $\mathrm{O}(33)-\mathrm{Na}-\mathrm{O}(14) \# 4$ & $98.0(2)$ \\
\hline & & $\mathrm{O}(23) \# 3-\mathrm{Na}-\mathrm{O}(14) \# 4$ & $98.4(2)$ \\
\hline $\mathrm{Mg}(2)-\mathrm{O}(5 \mathrm{~W})$ & $2.055(4)$ & $\mathrm{O}(13) \# 4-\mathrm{Na}-\mathrm{O}(14) \# 4$ & $70.3(2)$ \\
\hline \multirow[t]{2}{*}{$\mathrm{Mg}(2)-\mathrm{O}(6 \mathrm{~W})$} & $2.075(4)$ & & \\
\hline & & $\mathrm{O}(3 \mathrm{~W})-\mathrm{Mg}(1)-\mathrm{O}(4 \mathrm{~W})$ & $89.5(1)$ \\
\hline $\mathrm{Mg}(3)-\mathrm{O}(1 \mathrm{~W})$ & $2.065(4)$ & $\mathrm{O}(3 \mathrm{~W}) \# 5-\mathrm{Mg}(1)-\mathrm{O}(3 \mathrm{~W})$ & $90.6(2)$ \\
\hline \multirow[t]{2}{*}{$\operatorname{Mg}(3)-O(2 W)$} & $2.071(4)$ & $\mathrm{O}(3 \mathrm{~W})-\mathrm{Mg}(1)-\mathrm{O}(4 \mathrm{~W}) \# 6$ & 89.9(1) \\
\hline & & $\mathrm{O}(4 \mathrm{~W})-\mathrm{Mg}(1)-\mathrm{O}(4 \mathrm{~W}) \# 5$ & $90.1(2)$ \\
\hline $\mathrm{O}(12)-\mathrm{Fe}-\mathrm{O}(11)$ & $80.8(2)$ & $\mathrm{O}(3 \mathrm{~W})-\mathrm{Mg}(1)-\mathrm{O}(4 \mathrm{~W}) \# 5$ & $179.6(2)$ \\
\hline $\mathrm{O}(12)-\mathrm{Fe}-\mathrm{O}(31)$ & $92.2(1)$ & & \\
\hline $\mathrm{O}(11)-\mathrm{Fe}-\mathrm{O}(31)$ & $92.6(1)$ & $\mathrm{O}(5 \mathrm{~W})-\mathrm{Mg}(2)-\mathrm{O}(6 \mathrm{~W})$ & $90.6(1)$ \\
\hline $\mathrm{O}(12)-\mathrm{Fe}-\mathrm{O}(22)$ & $94.9(1)$ & $\mathrm{O}(5 \mathrm{~W}) \# 4-\mathrm{Mg}(2)-\mathrm{O}(5 \mathrm{~W})$ & $90.5(2)$ \\
\hline $\mathrm{O}(11)-\mathrm{Fe}-\mathrm{O}(22)$ & $93.1(2)$ & $\mathrm{O}(5 \mathrm{~W})-\mathrm{Mg}(2)-\mathrm{O}(6 \mathrm{~W}) \# 1$ & $89.0(1)$ \\
\hline $\mathrm{O}(31)-\mathrm{Fe}-\mathrm{O}(22)$ & $171.5(1)$ & $\mathrm{O}(6 \mathrm{~W})-\mathrm{Mg}(2)-\mathrm{O}(6 \mathrm{~W}) \# 1$ & $90.0(2)$ \\
\hline $\mathrm{O}(12)-\mathrm{Fe}-\mathrm{O}(21)$ & 93.4(1) & $\mathrm{O}(5 \mathrm{~W})-\mathrm{Mg}(2)-\mathrm{O}(6 \mathrm{~W}) \# 4$ & $178.8(2)$ \\
\hline $\mathrm{O}(11)-\mathrm{Fe}-\mathrm{O}(21)$ & $170.4(1)$ & & \\
\hline $\mathrm{O}(31)-\mathrm{Fe}-\mathrm{O}(21)$ & $95.2(2)$ & $\mathrm{O}(2 \mathrm{~W})-\mathrm{Mg}(3)-\mathrm{O}(1 \mathrm{~W})$ & $89.8(1)$ \\
\hline $\mathrm{O}(22)-\mathrm{Fe}-\mathrm{O}(21)$ & $79.8(1)$ & $\mathrm{O}(2 \mathrm{~W})-\mathrm{Mg}(3)-\mathrm{O}(2 \mathrm{~W}) \# 2$ & $90.3(2)$ \\
\hline $\mathrm{O}(12)-\mathrm{Fe}-\mathrm{O}(32)$ & $170.31(9)$ & $\mathrm{O}(2 \mathrm{~W})-\mathrm{Mg}(3)-\mathrm{O}(1 \mathrm{~W}) \# 2$ & 89.1(1) \\
\hline $\mathrm{O}(11)-\mathrm{Fe}-\mathrm{O}(32)$ & $92.9(2)$ & $\mathrm{O}(1 \mathrm{~W})-\mathrm{Mg}(3)-\mathrm{O}(1 \mathrm{~W}) \# 2$ & $90.7(2)$ \\
\hline $\mathrm{O}(31)-\mathrm{Fe}-\mathrm{O}(32)$ & $80.73(9)$ & $\mathrm{O}(2 \mathrm{~W})-\mathrm{Mg}(3)-\mathrm{O}(1 \mathrm{~W}) \# 3$ & $179.5(2)$ \\
\hline
\end{tabular}

Symmetry transformations used to generate equivalent atoms: (\#1) $-y, x-y+1, z ;(\# 2)-x+y,-x+1, z ;(\# 3)-y+1, x-y+1, z:$ (\#4) $-x+y-1,-x, \mathrm{z} ;(\# 5)-\mathrm{y}+1, \mathrm{x}-\mathrm{y}+2, \mathrm{z} ;(\# 6)-\mathrm{x}+\mathrm{y}-1$, $-\mathrm{x}+1, \mathrm{z}$

natural materials basically possess the same crystal and molecular structure as their synthetic counterparts.

\section{Vibrational spectra}

In order to extend our knowledge of the general physicochemical properties of the two synthetic minerals, we have measured and briefly analyzed their FTIR and Raman
Table 4 Bond lengths $[\AA ̊]$ and angles $\left[{ }^{\circ}\right]$ around the metals in zhemchuzhnikovite (M: Al/Fe)

\begin{tabular}{|c|c|c|c|}
\hline $\mathrm{M}-\mathrm{O}(11)$ & $1.971(4)$ & $\mathrm{O}(22)-\mathrm{M}-\mathrm{O}(11)$ & $92.2(2)$ \\
\hline $\mathrm{M}-\mathrm{O}(12)$ & $1.950(4)$ & $\mathrm{O}(32)-\mathrm{M}-\mathrm{O}(11)$ & $91.6(2)$ \\
\hline $\mathrm{M}-\mathrm{O}(21)$ & $1.948(4)$ & & \\
\hline $\mathrm{M}-\mathrm{O}(22)$ & $1.970(4)$ & $\mathrm{O}(14) \# 3-\mathrm{Na}-\mathrm{O}(33)$ & $99.4(2)$ \\
\hline $\mathrm{M}-\mathrm{O}(31)$ & $1.961(4)$ & $\mathrm{O}(14) \# 3-\mathrm{Na}-\mathrm{O}(23) \# 4$ & $99.6(2)$ \\
\hline \multirow[t]{2}{*}{$\mathrm{M}-\mathrm{O}(32)$} & $1.970(4)$ & $\mathrm{O}(33)-\mathrm{Na}-\mathrm{O}(23) \# 4$ & $95.8(2)$ \\
\hline & & $\mathrm{O}(14) \# 3-\mathrm{Na}-\mathrm{O}(34)$ & $164.9(2)$ \\
\hline $\mathrm{Na}-\mathrm{O}(33)$ & $2.332(4)$ & $\mathrm{O}(33)-\mathrm{Na}-\mathrm{O}(34)$ & $70.9(1)$ \\
\hline $\mathrm{Na}-\mathrm{O}(34)$ & $2.400(5)$ & $\mathrm{O}(23) \# 4-\mathrm{Na}-\mathrm{O}(34)$ & $93.0(2)$ \\
\hline $\mathrm{Na}-\mathrm{O}(14) \# 3$ & $2.313(6)$ & $\mathrm{O}(14) \# 3-\mathrm{Na}-\mathrm{O}(13) \# 3$ & $70.9(2)$ \\
\hline $\mathrm{Na}-\mathrm{O}(23) \# 4$ & $2.353(6)$ & $\mathrm{O}(33)-\mathrm{Na}-\mathrm{O}(13) \# 3$ & $96.6(2)$ \\
\hline $\mathrm{Na}-\mathrm{O}(24) \# 4$ & $2.420(4)$ & $\mathrm{O}(23) \# 4-\mathrm{Na}-\mathrm{O}(13) \# 3$ & $165.5(1)$ \\
\hline \multirow[t]{2}{*}{$\mathrm{Na}-\mathrm{O}(13) \# 3$} & $2.398(6)$ & $\mathrm{O}(34)-\mathrm{Na}-\mathrm{O}(13) \# 3$ & $98.2(2)$ \\
\hline & & $\mathrm{O}(14) \# 3-\mathrm{Na}-\mathrm{O}(24) \# 4$ & $91.4(1)$ \\
\hline $\mathrm{Mg}(1)-\mathrm{O}(3 \mathrm{~W})$ & $2.071(4)$ & $\mathrm{O}(33)-\mathrm{Na}-\mathrm{O}(24) \# 4$ & $164.6(2)$ \\
\hline \multirow[t]{2}{*}{$\mathrm{Mg}(1)-\mathrm{O}(4 \mathrm{~W})$} & $2.063(4)$ & $\mathrm{O}(23) \# 4-\mathrm{Na}-\mathrm{O}(24) \# 4$ & $71.5(1)$ \\
\hline & & $\mathrm{O}(34)-\mathrm{Na}-\mathrm{O}(24) \# 4$ & $100.5(2)$ \\
\hline $\mathrm{Mg}(2)-\mathrm{O}(5 \mathrm{~W})$ & $2.048(4)$ & $\mathrm{O}(13) \# 3-\mathrm{Na}-\mathrm{O}(24) \# 4$ & $97.3(2)$ \\
\hline \multirow[t]{2}{*}{$\mathrm{Mg}(2)-\mathrm{O}(6 \mathrm{~W})$} & $2.089(4)$ & & \\
\hline & & $\mathrm{O}(3 \mathrm{~W})-\mathrm{Mg}(1)-\mathrm{O}(4 \mathrm{~W})$ & $89.3(1)$ \\
\hline $\operatorname{Mg}(3)-O(1 W)$ & $2.069(4)$ & $\mathrm{O}(3 \mathrm{~W}) \# 5-\mathrm{Mg}(1)-\mathrm{O}(3 \mathrm{~W})$ & $90.5(2)$ \\
\hline \multirow[t]{2}{*}{$\mathrm{Mg}(3)-\mathrm{O}(2 \mathrm{~W})$} & $2.076(4)$ & $\mathrm{O}(3 \mathrm{~W})-\mathrm{Mg}(1)-\mathrm{O}(4 \mathrm{~W}) \# 6$ & $90.1(1)$ \\
\hline & & $\mathrm{O}(4 \mathrm{~W}) \# 6-\mathrm{Mg}(1)-\mathrm{O}(4 \mathrm{~W})$ & $90.0(2)$ \\
\hline $\mathrm{O}(21)-\mathrm{M}-\mathrm{O}(12)$ & $92.7(2)$ & $\mathrm{O}(3 \mathrm{~W})-\mathrm{Mg}(1)-\mathrm{O}(4 \mathrm{~W}) \# 5$ & $179.3(2)$ \\
\hline $\mathrm{O}(21)-\mathrm{M}-\mathrm{O}(31)$ & $93.8(2)$ & & \\
\hline $\mathrm{O}(12)-\mathrm{M}-\mathrm{O}(31)$ & $92.3(2)$ & $\mathrm{O}(5 \mathrm{~W})-\mathrm{Mg}(2)-\mathrm{O}(6 \mathrm{~W})$ & $90.7(2)$ \\
\hline $\mathrm{O}(21)-\mathrm{M}-\mathrm{O}(22)$ & $81.8(1)$ & $\mathrm{O}(5 \mathrm{~W}) \# 1-\mathrm{Mg}(2)-\mathrm{O}(5 \mathrm{~W})$ & $91.0(2)$ \\
\hline $\mathrm{O}(12)-\mathrm{M}-\mathrm{O}(22)$ & $94.4(1)$ & $\mathrm{O}(5 \mathrm{~W})-\mathrm{Mg}(2)-\mathrm{O}(6 \mathrm{~W}) \# 1$ & $88.9(2)$ \\
\hline $\mathrm{O}(31)-\mathrm{M}-\mathrm{O}(22)$ & $172.1(2)$ & $\mathrm{O}(6 \mathrm{~W})-\mathrm{Mg}(2)-\mathrm{O}(6 \mathrm{~W}) \# 1$ & $89.4(2)$ \\
\hline $\mathrm{O}(21)-\mathrm{M}-\mathrm{O}(32)$ & $93.9(2)$ & $\mathrm{O}(5 \mathrm{~W})-\mathrm{Mg}(2)-\mathrm{O}(6 \mathrm{~W}) \# 3$ & $178.3(2)$ \\
\hline $\mathrm{O}(12)-\mathrm{M}-\mathrm{O}(32)$ & $171.6(1)$ & & \\
\hline $\mathrm{O}(31)-\mathrm{M}-\mathrm{O}(32)$ & $82.0(1)$ & $\mathrm{O}(2 \mathrm{~W})-\mathrm{Mg}(3)-\mathrm{O}(1 \mathrm{~W})$ & $90.4(2)$ \\
\hline $\mathrm{O}(22)-\mathrm{M}-\mathrm{O}(32)$ & $91.7(2)$ & $\mathrm{O}(2 \mathrm{~W})-\mathrm{Mg}(3)-\mathrm{O}(2 \mathrm{~W}) \# 2$ & $90.2(2)$ \\
\hline $\mathrm{O}(21)-\mathrm{M}-\mathrm{O}(11)$ & $171.9(1)$ & $\mathrm{O}(2 \mathrm{~W}) \# 4-\mathrm{Mg}(3)-\mathrm{O}(1 \mathrm{~W})$ & 89.2(1) \\
\hline $\mathrm{O}(12)-\mathrm{M}-\mathrm{O}(11)$ & $82.4(2)$ & $\mathrm{O}(1 \mathrm{~W})-\mathrm{Mg}(3)-\mathrm{O}(1 \mathrm{~W}) \# 2$ & $90.2(2)$ \\
\hline $\mathrm{O}(31)-\mathrm{M}-\mathrm{O}(11)$ & $92.8(1)$ & $\mathrm{O}(2 \mathrm{~W})-\mathrm{Mg}(3)-\mathrm{O}(1 \mathrm{~W}) \# 4$ & $179.2(2)$ \\
\hline
\end{tabular}

Symmetry transformations used to generate equivalent atoms: (\#1) $-\mathrm{y}, \mathrm{x}-\mathrm{y}+1, \mathrm{z} ;(\# 2)-\mathrm{x}+\mathrm{y},-\mathrm{x}+1, \mathrm{z} ;(\# 3)-\mathrm{x}+\mathrm{y}-1,-\mathrm{x}, \mathrm{z}$; (\#4) $-\mathrm{y}+1, \mathrm{x}-\mathrm{y}+1, \mathrm{z} ;(\# 5)-\mathrm{y}+1, \mathrm{x}-\mathrm{y}+2, \mathrm{z} ;(\# 6)-\mathrm{x}+\mathrm{y}-1$, $-\mathrm{x}+1, \mathrm{z}$

spectra. In the case of the two analogous minerals, only the IR spectrum of a sample of zhemchuzhnikovite from the Chai Tumus coal deposit (Yakutia) has so far been published and collected in an atlas of IR spectra of mineral species (Chukanov 2014).

The spectra of both synthetic complexes are rather similar in their general appearance, band patterns and intensity distribution, and show also close analogies to the spectrum 
Table 5 Hydrogen bond distances and angles in synthetic stepanovite
Table 6 Hydrogen bond distances and angles in synthetic zhemchuzhnikovite

\begin{tabular}{lllllll}
\hline D-H & $\mathrm{d}(\mathrm{D}-\mathrm{H})$ & $\mathrm{d}(\mathrm{H} \cdots \mathrm{A})$ & $<(\mathrm{D}-\mathrm{H} \cdots \mathrm{A})$ & $\mathrm{d}(\mathrm{D} \cdots \mathrm{A})$ & $\mathrm{A}$ & Symm. operation \\
\hline O1W-H1A & $0.85(1)$ & $2.01(2)$ & $171(6)$ & $2.858(6)$ & $\mathrm{O} 23$ & {$[-\mathrm{y}+1, \mathrm{x}-\mathrm{y}+1, \mathrm{z}]$} \\
O1W-H1B & $0.85(1)$ & $1.95(3)$ & $156(6)$ & $2.754(7)$ & $\mathrm{O} 7 \mathrm{~W}$ & {$[-\mathrm{x}+\mathrm{y},-\mathrm{x}+1, \mathrm{z}]$} \\
O2W-H2A & $0.85(1)$ & $2.17(3)$ & $150(5)$ & $2.935(6)$ & $\mathrm{O} 2$ & \\
O2W-H2B & $0.85(1)$ & $1.89(2)$ & $168(6)$ & $2.731(7)$ & O7W & {$[\mathrm{x}, \mathrm{x}-\mathrm{y}+1, \mathrm{z}-1 / 2]$} \\
O3W-H3A & $0.85(1)$ & $2.03(2)$ & $165(6)$ & $2.861(6)$ & O24 & {$[-\mathrm{x}+\mathrm{y}-1,-\mathrm{x}+1, \mathrm{z}]$} \\
O3W-H3B & $0.86(1)$ & $1.89(2)$ & $164(6)$ & $2.727(6)$ & O9W & {$[-\mathrm{x}+\mathrm{y}, \mathrm{y}, \mathrm{z}-1 / 2]$} \\
O4W-H4A & $0.85(1)$ & $2.06(1)$ & $169(5)$ & $2.902(6)$ & O12 & \\
O4W-H4B & $0.86(1)$ & $1.92(2)$ & $159(6)$ & $2.737(6)$ & O9W & {$[-\mathrm{y}+1, \mathrm{x}-\mathrm{y}+1, \mathrm{z}]$} \\
O5W-H5A & $0.85(1)$ & $1.88(2)$ & $171(6)$ & $2.728(7)$ & O8W & {$[-\mathrm{x}+\mathrm{y}, \mathrm{y}, \mathrm{z}-1 / 2]$} \\
O5W-H5B & $0.85(1)$ & $2.00(2)$ & $168(6)$ & $2.836(6)$ & O13 & {$[-\mathrm{x}+\mathrm{y}-1,-\mathrm{x}, \mathrm{z}]$} \\
O6W-H6A & $0.86(1)$ & $1.92(2)$ & $164(6)$ & $2.751(6)$ & O8W & {$[-\mathrm{x}+\mathrm{y},-\mathrm{x}+1, \mathrm{z}]$} \\
O6W-H6B & $0.85(1)$ & $2.19(2)$ & $166(5)$ & $3.027(6)$ & O31 & {$[-\mathrm{x}+\mathrm{y}-1,-\mathrm{x}, \mathrm{z}]$} \\
O7W-H7A & $0.86(1)$ & $1.94(2)$ & $171(5)$ & $2.796(7)$ & O21 & {$[-\mathrm{y}+1, \mathrm{x}-\mathrm{y}+1, \mathrm{z}]$} \\
O7W-H7B & $0.86(1)$ & $1.94(3)$ & $150(5)$ & $2.721(8)$ & O34 & {$[-\mathrm{x}+\mathrm{y}, \mathrm{y}, \mathrm{z}+1 / 2]$} \\
O8W-H8A & $0.85(1)$ & $1.98(2)$ & $157(5)$ & $2.780(6)$ & O11 & {$[-\mathrm{x}+\mathrm{y}, \mathrm{y}, \mathrm{z}+1 / 2]$} \\
O8W-H8B & $0.86(1)$ & $1.90(2)$ & $164(5)$ & $2.733(7)$ & O33 & {$[-\mathrm{y}+1, \mathrm{x}-\mathrm{y}+1, \mathrm{z}]$} \\
O9W-H9A & $0.86(1)$ & $1.99(3)$ & $149(5)$ & $2.754(7)$ & O22 & {$[-\mathrm{x}+\mathrm{y}, \mathrm{y}, \mathrm{z}+1 / 2]$} \\
O9W-H9B & $0.86(1)$ & $1.92(2)$ & $164(5)$ & $2.752(7)$ & O14 & {$[\mathrm{x}+1, \mathrm{y}, \mathrm{z}]$} \\
\hline
\end{tabular}

\begin{tabular}{|c|c|c|c|c|c|c|}
\hline D-H & $\mathrm{d}(\mathrm{D}-\mathrm{H})$ & $\mathrm{d}(\mathrm{H} \cdots \mathrm{A})$ & $<(\mathrm{D}-\mathrm{H} \cdots \mathrm{A})$ & $\mathrm{d}(\mathrm{D} \cdots \mathrm{A})$ & A & Symm. operation \\
\hline O1W-H1A & $0.86(1)$ & $1.99(2)$ & $165(6)$ & $2.832(7)$ & $\mathrm{O} 23$ & {$[-\mathrm{y}+1, \mathrm{x}-\mathrm{y}+1, \mathrm{z}]$} \\
\hline O1W-H1B & $0.86(1)$ & $1.91(1)$ & $169(6)$ & $2.756(7)$ & $\mathrm{O} 7 \mathrm{~W}$ & {$[-x+y,-x+1, z]$} \\
\hline $\mathrm{O} 2 \mathrm{~W}-\mathrm{H} 2 \mathrm{~A}$ & $0.86(1)$ & $2.09(2)$ & $163(6)$ & $2.926(6)$ & $\mathrm{O} 32$ & \\
\hline $\mathrm{O} 2 \mathrm{~W}-\mathrm{H} 2 \mathrm{~B}$ & $0.86(1)$ & $1.90(2)$ & $157(5)$ & $2.713(7)$ & $\mathrm{O} 7 \mathrm{~W}$ & {$[x, x-y+1, z-1 / 2]$} \\
\hline $\mathrm{O} 3 \mathrm{~W}-\mathrm{H} 3 \mathrm{~A}$ & $0.86(1)$ & $1.88(2)$ & $168(8)$ & $2.723(6)$ & O9W & {$[-x+y, y, z-1 / 2]$} \\
\hline $\mathrm{O} 3 \mathrm{~W}-\mathrm{H} 3 \mathrm{~B}$ & $0.86(1)$ & $2.03(2)$ & $162(5)$ & $2.859(7)$ & $\mathrm{O} 24$ & {$[-\mathrm{x}+\mathrm{y}-1,-\mathrm{x}+1, \mathrm{z}]$} \\
\hline $\mathrm{O} 4 \mathrm{~W}-\mathrm{H} 4 \mathrm{~A}$ & $0.86(1)$ & $1.90(2)$ & $169(7)$ & $2.749(6)$ & O9W & {$[-y+1, x-y+1, z]$} \\
\hline $\mathrm{O} 4 \mathrm{~W}-\mathrm{H} 4 \mathrm{~B}$ & $0.86(1)$ & $2.08(2)$ & $158(5)$ & $2.887(6)$ & $\mathrm{O} 12$ & \\
\hline O5W-H5A & $0.86(1)$ & $1.88(2)$ & $172(8)$ & $2.729(7)$ & O8W & {$[-x+y, y, z-1 / 2]$} \\
\hline O5W-H5B & $0.86(1)$ & $2.02(3)$ & $158(6)$ & $2.835(7)$ & $\mathrm{O} 13$ & {$[-\mathrm{x}+\mathrm{y}-1,-\mathrm{x}, \mathrm{z}]$} \\
\hline O6W-H6A & $0.86(1)$ & $1.96(3)$ & $154(6)$ & $2.757(7)$ & O8W & {$[-\mathrm{x}+\mathrm{y},-\mathrm{x}+1, \mathrm{z}]$} \\
\hline O6W-H6B & $0.86(1)$ & $2.24(3)$ & $147(5)$ & $3.002(7)$ & $\mathrm{O} 31$ & {$[-\mathrm{x}+\mathrm{y}-1,-\mathrm{x}, \mathrm{z}]$} \\
\hline O7W-H7A & $0.86(1)$ & $1.96(3)$ & $146(5)$ & $2.723(7)$ & $\mathrm{O} 34$ & {$[-x+y, y, z+1 / 2]$} \\
\hline O7W-H7B & $0.86(1)$ & $1.94(2)$ & $173(6)$ & $2.798(7)$ & $\mathrm{O} 21$ & {$[-\mathrm{y}+1, \mathrm{x}-\mathrm{y}+1, \mathrm{z}]$} \\
\hline O8W-H8A & $0.86(1)$ & $1.99(3)$ & $151(6)$ & $2.771(6)$ & $\mathrm{O} 11$ & {$[-x+y, y, z+1 / 2]$} \\
\hline O8W-H8B & $0.86(1)$ & $1.88(2)$ & $170(6)$ & $2.729(7)$ & $\mathrm{O} 33$ & {$[-\mathrm{y}+1, \mathrm{x}-\mathrm{y}+1, \mathrm{z}]$} \\
\hline O9W-H9A & $0.86(1)$ & $1.90(2)$ & $166(6)$ & $2.737(7)$ & $\mathrm{O} 14$ & {$[x+1, y, z]$} \\
\hline O9W-H9B & $0.86(1)$ & $2.03(4)$ & $142(5)$ & $2.759(6)$ & $\mathrm{O} 22$ & {$[-x+y, y, z+1 / 2]$} \\
\hline
\end{tabular}

of the mentioned natural sample. Only some minor differences are observed in the IR spectra, in the spectral region below $1000 \mathrm{~cm}^{-1}$.

The obtained spectra have been analyzed on the basis of the classic papers of Fujita et al. (1962a, b) on the vibrational behavior of $\mathrm{K}_{2}\left[\mathrm{M}^{\mathrm{II}}\left(\mathrm{C}_{2} \mathrm{O}_{4}\right)_{2}\right] \cdot \mathrm{nH}_{2} \mathrm{O}$ and $\mathrm{K}_{3}\left[\mathrm{M}^{\mathrm{III}}\left(\mathrm{C}_{2} \mathrm{O}_{4}\right)_{3}\right] \cdot 3 \mathrm{H}_{2} \mathrm{O}$ complexes (cf. also Nakamoto 2009) and also using information derived from our numerous previous studies on metallic oxalato complexes (Baran 2014) and from the recently investigated related species $\mathrm{Na}\left[\mathrm{Mg}\left(\mathrm{H}_{2} \mathrm{O}\right)_{6}\right]$ $\left[\mathrm{M}\left(\mathrm{C}_{2} \mathrm{O}_{4}\right)_{3}\right] \cdot 3 \mathrm{H}_{2} \mathrm{O}$ (with $\mathrm{M}=\mathrm{Cr}, \mathrm{Al}$ ) (Piro et al. 2015).

As the $\left[\mathrm{M}\left(\mathrm{C}_{2} \mathrm{O}_{4}\right)_{3}\right]^{3-}$ skeleton of the investigated complexes posses approximately $\mathrm{D}_{3}$-symmetry, its 51 internal vibration modes are distributed as follows:

$\Gamma_{v i b}=8 A_{1}+9 A_{2}+17 E$

where the $A_{1}$ species are Raman active, the $A_{2}$ species infrared active and the $E$ species are active in both the Raman 
Table 7 Crystal and chemical data of synthetic and natural stepanovite

\begin{tabular}{lll}
\hline & Synthetic stepanovite & Natural stepanovite $^{\mathrm{a}}$ \\
\hline Chemical formula & $\mathrm{NaMg}\left[\mathrm{Fe}\left(\mathrm{C}_{2} \mathrm{O}_{4}\right)_{3} \cdot 9 \mathrm{H}_{2} \mathrm{O}\right.$ & $\mathrm{NaMg}\left[\mathrm{Fe}\left(\mathrm{C}_{2} \mathrm{O}_{4}\right)_{3} \cdot 8-\right.$ \\
& & $9 \mathrm{H}_{2} \mathrm{O}$ \\
Crystal system & Trigonal & Trigonal \\
Space group & $\mathrm{P} 3 \mathrm{c} 1$ & Unknown \\
$\mathrm{a}(\AA)$ & $17.0483(4)$ & $9.85^{\mathrm{b}}$ \\
$\mathrm{c}(\AA)$ & $12.4218(4)$ & 36.67 \\
$Z$ & 6 & 6 \\
Density $\left(\mathrm{g} \mathrm{cm}^{-3}\right)$ & 1.687 (calc) & $1.69(\mathrm{exp}), 1.69$ (calc) \\
\hline
\end{tabular}

${ }^{\text {a }}$ Fleischer (1964) and Anthony et al. (2004)

b The previously reported a-value is inconsistent. We have recalculated this value on the basis of the reported c-value and a:c ratio

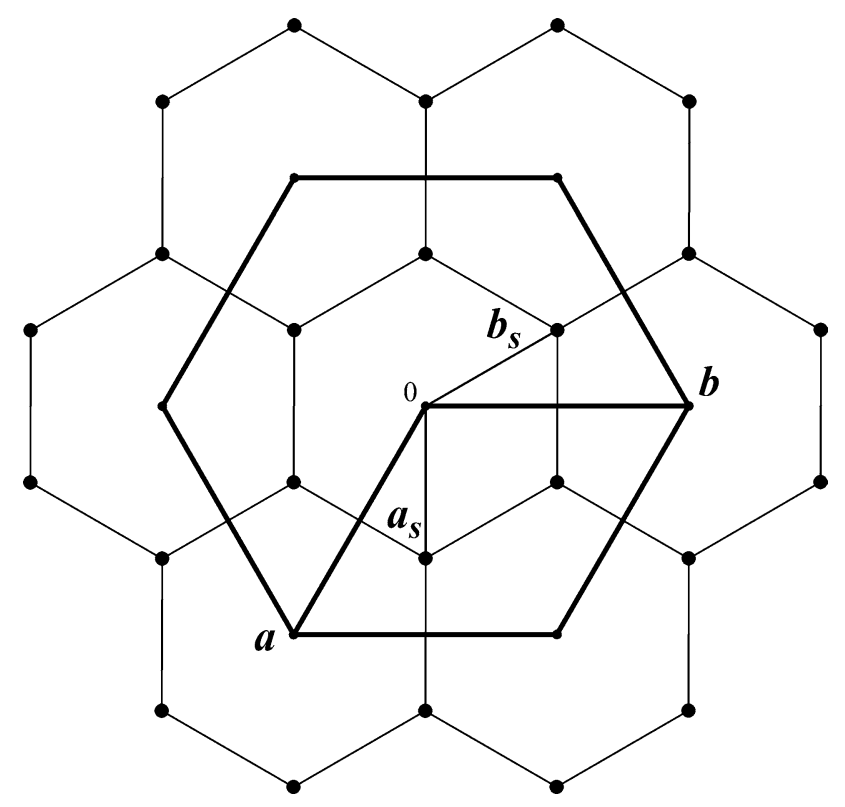

Fig. 2 Geometrical relationship between synthetic (thick lines) and natural (thin lines) stepanovite hexagonal lattices. Synthetic stepanovite: crystal cell $(a, b)$ vectors. Natural stepanovite: unit sub-cell $\left(a_{S}\right.$, $b_{S}$ ) vectors

and the infrared (Edwards and Russell 1998). Therefore, in the experimental spectra, one can expect vibrations which present similar energies in both spectra and others which can be found in only one of the spectra.

The FTIR and Raman spectra of $\mathrm{Na}\left[\mathrm{Mg}\left(\mathrm{H}_{2} \mathrm{O}\right)_{6}\right]$ $\left[\mathrm{Fe}\left(\mathrm{C}_{2} \mathrm{O}_{4}\right)_{3}\right] \cdot 3 \mathrm{H}_{2} \mathrm{O}$ are shown in Fig. 4 and those of $\mathrm{Na}\left[\mathrm{Mg}\left(\mathrm{H}_{2} \mathrm{O}\right)_{6}\right]\left[\mathrm{Al}_{0.55} \mathrm{Fe}_{0.45}\left(\mathrm{C}_{2} \mathrm{O}_{4}\right)_{3}\right] \cdot 3 \mathrm{H}_{2} \mathrm{O}$ in Fig. 5. The assignments proposed for the spectra of both compounds are presented in Table 9 and briefly discussed as follows:

- The characteristic $\mathrm{O}-\mathrm{H}$ stretching vibrations of the water molecules are seen as a strong band multiplet in the IR spectra and, as usual, only in the form of some weak signals in the respective Raman spectra.

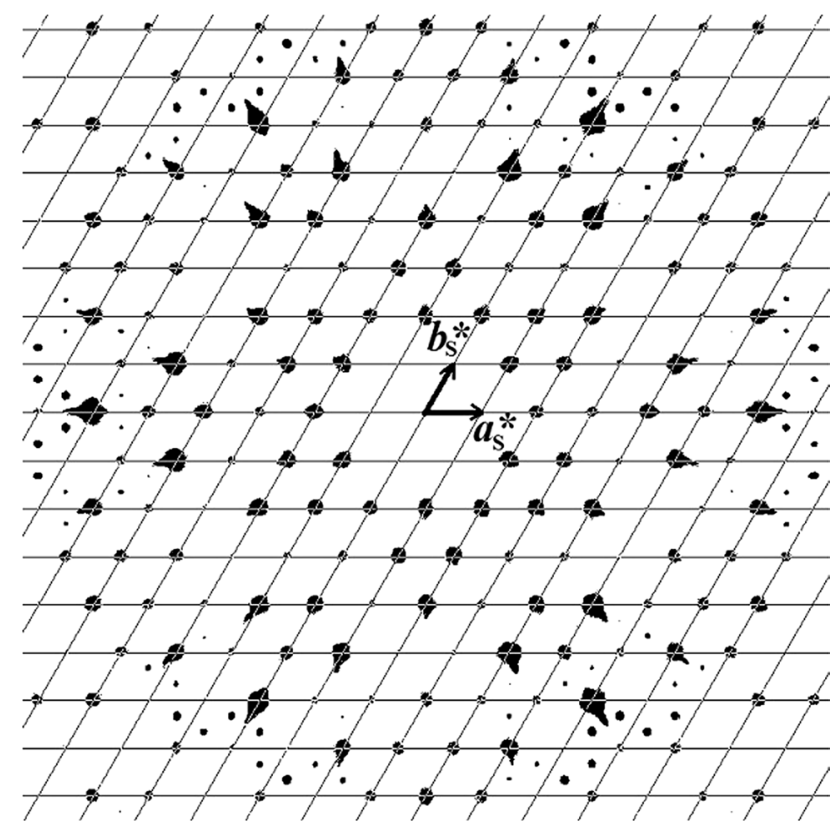

Fig. 3 Precession photo-like rendering of CCD diffractometric data corresponding to the $h k i O$ layer of synthetic stepanovite. For clarity, background scattering has been removed and as a guide to the eyes the reciprocal $h k i 0$ lattice mesh of the published substructure is included in the figure. Note that the most intense X-ray diffraction spots in the layer lay on the substructure mesh. All reflections, including the much weaker high-resolution diffraction spots, are indexed in the superstructure cell reported in this work

The band broadening and the appearance of different well-defined peaks are surely related to the presence of the different kinds of water molecules in the structures, as discussed above. The measured wave numbers for these vibrations clearly satisfy known correlations between $\mathrm{OH}$-stretching frequencies and hydrogen bond distances (cf., for example, Libowitzky 1999), and from the spectroscopic point of view, these hydrogen bridges classify as mean-strength bridges (Siebert 1966). The deformational mode of 
Table 8 Crystal and chemical data of synthetic and natural zhemchuzhnikovite

\begin{tabular}{lll}
\hline & Synth. zhemchuzhnikovite & Natur. zhemchuzhnikovite $^{\mathrm{a}}$ \\
\hline Chemical formula & $\mathrm{NaMg}\left[\mathrm{Al}_{\mathrm{x}} \mathrm{Fe}_{1-\mathrm{x}}\left(\mathrm{C}_{2} \mathrm{O}_{4}\right)_{3} \cdot 9 \mathrm{H}_{2} \mathrm{O}\right.$ & $\mathrm{NaMg}\left[\mathrm{Al}_{\mathrm{x}} \mathrm{Fe}_{1-\mathrm{x}}\left(\mathrm{C}_{2} \mathrm{O}_{4}\right)_{3} \cdot 8 \mathrm{H}_{2} \mathrm{O}\right.$ \\
& $\mathrm{x}=0.55$ & $\mathrm{x}=0.62$ \\
Crystal system & Trigonal & Trigonal \\
Space group & $\mathrm{P} 3 \mathrm{c} 1$ & Unknown \\
$\mathrm{a}(\AA)$ & $16.8852(5)$ & $16.67(5)$ \\
$\mathrm{c}(\AA)$ & $12.5368(5)$ & $12.51(3)$ \\
$\mathrm{Z}$ & 6 & 6 \\
Density $\left(\mathrm{g} \mathrm{cm}^{-3}\right)$ & $1.652(\mathrm{calc})$ & $1.69(\mathrm{exp}), 1.66(\mathrm{calc})$ \\
\hline
\end{tabular}

a Fleischer (1964) and Anthony et al. (2004)

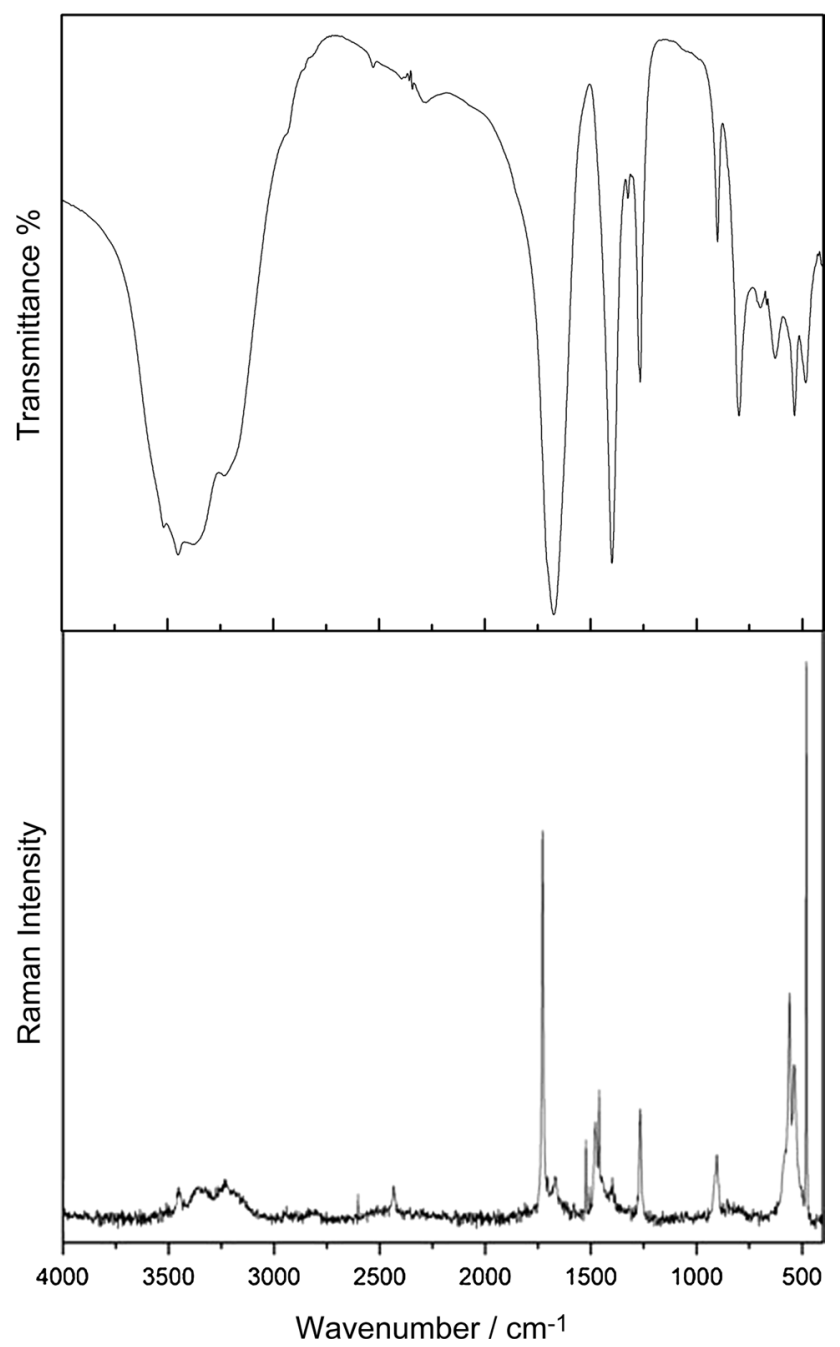

Fig. 4 FTIR (above) and FT-Raman spectra (below) of $\mathrm{Na}\left[\mathrm{Mg}\left(\mathrm{H}_{2} \mathrm{O}\right)_{6}\right]\left[\mathrm{Fe}\left(\mathrm{C}_{2} \mathrm{O}_{4}\right)_{3}\right] \cdot 3 \mathrm{H}_{2} \mathrm{O}$ in the frequency range between 4000 and $400 \mathrm{~cm}^{-1}$

the $\mathrm{H}_{2} \mathrm{O}$ molecules are surely overlapped by the strong IR bands located above $1600 \mathrm{~cm}^{-1}$. In the case of $\mathrm{Na}\left[\mathrm{Mg}\left(\mathrm{H}_{2} \mathrm{O}\right)_{6}\right]\left[\mathrm{Fe}\left(\mathrm{C}_{2} \mathrm{O}_{4}\right)_{3}\right] \cdot 3 \mathrm{H}_{2} \mathrm{O}$, a weak band doublet observed in the IR spectrum $\left(696 / 627 \mathrm{~cm}^{-1}\right)$ was

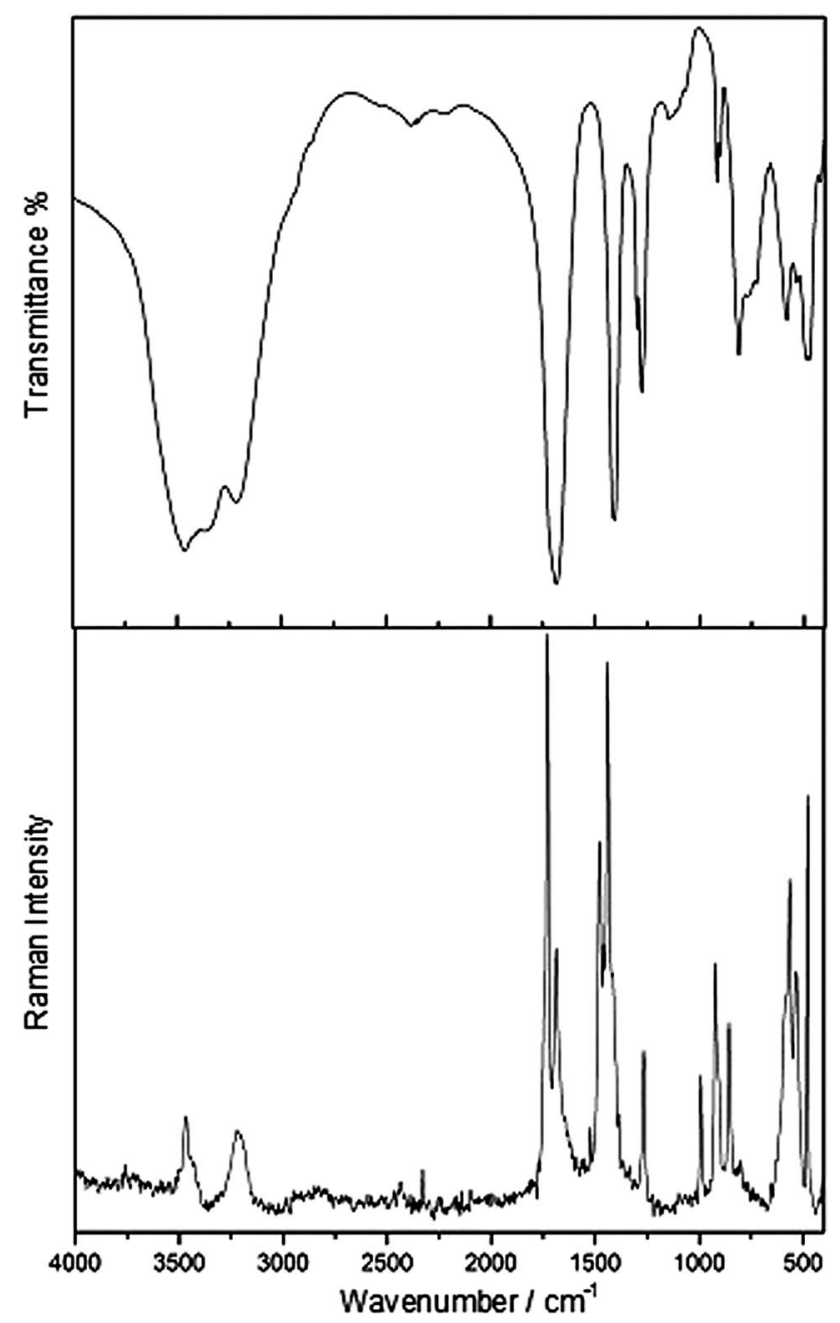

Fig. 5 FTIR (above) and FT-Raman spectra (below) of $\mathrm{Na}\left[\mathrm{Mg}\left(\mathrm{H}_{2} \mathrm{O}\right)_{6}\right]\left[\mathrm{Al}_{0.55} \mathrm{Fe}_{0.45}\left(\mathrm{C}_{2} \mathrm{O}_{4}\right)_{3}\right] \cdot 3 \mathrm{H}_{2} \mathrm{O}$ in the frequency range between 4000 and $400 \mathrm{~cm}^{-1}$

tentatively assigned to one of the $\rho\left(\mathrm{H}_{2} \mathrm{O}\right)$ motions. Additional bands of this type may also be located at around $450-480 \mathrm{~cm}^{-1}$ as suggested from data available for $\left[\mathrm{Mg}\left(\mathrm{H}_{2} \mathrm{O}\right)_{6}\right]^{2+}$ complexes (Nakamoto 2009). 
Table 9 Assignment of the vibrational spectra of the two investigated synthetic minerals (band positions in $\mathrm{cm}^{-1}$ )

\begin{tabular}{|c|c|c|c|c|}
\hline \multicolumn{2}{|c|}{$\mathrm{NaMg}\left[\mathrm{Fe}\left(\mathrm{C}_{2} \mathrm{O}_{4}\right)_{3}\right] \cdot 9 \mathrm{H}_{2} \mathrm{O}$} & \multicolumn{2}{|c|}{$\mathrm{NaMg}\left[\mathrm{Al}_{0.55} \mathrm{Fe}_{0.45}\left(\mathrm{C}_{2} \mathrm{O}_{4}\right)_{3}\right] \cdot 9 \mathrm{H}_{2} \mathrm{O}$} & \multirow[t]{2}{*}{ Assignment } \\
\hline Infrared & Raman & Infrared & Raman & \\
\hline $3518 \mathrm{w}, 3450$ vs & $3450 \mathrm{w}$ & 3458 vs & $3467 \mathrm{~m}$ & \\
\hline 3371 vs & $3350 \mathrm{w}$ & $3355 \mathrm{sh}$ & & $v(\mathrm{OH})$ water \\
\hline $3233 \mathrm{~m}$ & $\begin{array}{l}3275 \mathrm{w} \\
1728 \mathrm{vs}, 1666 \mathrm{w}\end{array}$ & $3219 \mathrm{~m}$ & $\begin{array}{l}3222 \mathrm{~m} \\
1788 \mathrm{vs}, 1688 \mathrm{~s}\end{array}$ & $\nu_{\mathrm{as}}(\mathrm{C}=\mathrm{O})$ \\
\hline 1674 vs & & 1684 vs & & $\nu_{\mathrm{as}}(\mathrm{C}=\mathrm{O})$ \\
\hline 1400 vs & $\begin{array}{l}1478 \mathrm{~m}, 1460 \mathrm{~m} \\
1523 \mathrm{~m} \\
1398 \mathrm{~m}\end{array}$ & 1404 vs & $\begin{array}{l}1479 \mathrm{~s}, 1440 \mathrm{vs} \\
1520 \mathrm{w}\end{array}$ & $\begin{array}{l}v_{s}(\mathrm{CO})+v(\mathrm{CC}) \\
\text { Combination }\end{array}$ \\
\hline $1324 \mathrm{vw}, 1265 \mathrm{~s}$ & $1267 \mathrm{~s}$ & $\begin{array}{l}1298 \mathrm{w}, 1276 \mathrm{~s} \\
1146 \mathrm{vw}\end{array}$ & $1266 \mathrm{~m}$ & $\begin{array}{l}\nu_{\mathrm{s}}(\mathrm{CO})+\delta(\mathrm{OC}=\mathrm{O}) \\
\text { Combination }\end{array}$ \\
\hline $900 \mathrm{~m}$ & $903 \mathrm{~m}$ & $916 \mathrm{~m}, 901 \mathrm{w}$ & $991 \mathrm{~m}, 923 \mathrm{~s}$ & $v_{\mathrm{s}}(\mathrm{CO})+\delta(\mathrm{OC}=\mathrm{O})$ \\
\hline $798 \mathrm{~s}$ & & $\begin{array}{l}811 \mathrm{~s} \\
762 \mathrm{sh}, 729 \mathrm{~m}\end{array}$ & $856 \mathrm{~m}$ & $\begin{array}{l}\delta(\mathrm{OC}=\mathrm{O} \\
\delta(\mathrm{OC}=\mathrm{O}\end{array}$ \\
\hline $696 \mathrm{w}, 627 \mathrm{~m}$ & $599 \mathrm{~s}$ & $581 \mathrm{~m}$ & $565 \mathrm{~s}$ & $\begin{array}{l}\rho\left(\mathrm{H}_{2} \mathrm{O}\right)(?) \\
\nu(\mathrm{MO})+v(\mathrm{CC})\end{array}$ \\
\hline $\begin{array}{l}536 \mathrm{~m}, 483 \mathrm{~m} \\
483 \mathrm{~m} \\
423 \mathrm{vw}\end{array}$ & $\begin{array}{l}537 \mathrm{~s}, 480 \mathrm{vs} \\
480 \mathrm{vs}\end{array}$ & $\begin{array}{l}535 \mathrm{w}, 490 \mathrm{~m} \\
490 \mathrm{~m}, 475 \mathrm{~m} \\
419 \mathrm{vw}\end{array}$ & $\begin{array}{l}533 \mathrm{~m}, 480 \mathrm{~s} \\
479 \mathrm{vs}\end{array}$ & $\begin{array}{l}v(\mathrm{MO})+v(\mathrm{CC}) \\
\delta_{\text {ring }}+\delta(\mathrm{OC}=\mathrm{O}) \\
v(\mathrm{MO})+\delta(\mathrm{OC}=\mathrm{O})\end{array}$ \\
\hline
\end{tabular}

$v s$ very strong, $s$ strong, $m$ medium, $w$ weak, $v w$ very weak, $s h$ shoulder
- The antisymmetric $\mathrm{C}=\mathrm{O}$ stretching vibration generates three spectral bands: one in the form of a well-defined doublet in the Raman spectra and the other one in the IR spectra. In the case of the Raman spectrum of synthetic stepanovite, the lower energy component of the mentioned doublet is unexpectedly weak.

- As derived from theoretical studies (Fujita et al. 1962a, b), and as a consequence of the low symmetry of the chelate ring and the fact that the force constants for the $v(\mathrm{C}-\mathrm{O}), v(\mathrm{C}-\mathrm{C})$ and $v(\mathrm{M}-\mathrm{O})$ vibrations are of similar magnitude, bands related to the symmetric $\mathrm{C}-\mathrm{O}$ stretching modes are strongly coupled with some other vibrations.

- Although the $\mathrm{M}(\mathrm{III})-\mathrm{O}$ bonds in $\mathrm{Na}\left[\mathrm{Mg}\left(\mathrm{H}_{2} \mathrm{O}\right)_{6}\right]$ $\left[\mathrm{Al}_{0.55} \mathrm{Fe}_{0.45}\left(\mathrm{C}_{2} \mathrm{O}_{4}\right)_{3}\right] \cdot 3 \mathrm{H}_{2} \mathrm{O}$ are somewhat shorter than those of $\mathrm{Fe}(\mathrm{III})-\mathrm{O}$ bonds in $\mathrm{Na}\left[\mathrm{Mg}\left(\mathrm{H}_{2} \mathrm{O}\right)_{6}\right]$ $\left[\mathrm{Fe}\left(\mathrm{C}_{2} \mathrm{O}_{4}\right)_{3}\right] \cdot 3 \mathrm{H}_{2} \mathrm{O}$, this is not reflected in the bands assigned to $v(\mathrm{MO})$ stretchings, probably due to the mentioned coupling effects. Notwithstanding, this expected $\mathrm{M}(\mathrm{III})-\mathrm{O}$ bond reinforcement, although not directly evident in the spectra, shows a certain impact on the oxalate vibrations. As can be seen from Table 9, v(C=O) vibrations are always at higher energies in the case of synthetic zhemchuzhnikovite. Essentially one may expect that a reinforcement of the $\mathrm{M}-\mathrm{O}$ bond causes a slight decrease in the strength of the $\mathrm{C}-\mathrm{O}$ bonds and a concomitant reinforcement of the uncoordinated $\mathrm{C}=\mathrm{O}$ bonds (Fujita et al. 1962a). The decrease in energy of the $\mathrm{C}-\mathrm{O}$ bonds is not clearly visible in the present case, surely due to the strong coupled nature of this vibration.

\section{Conclusions}

From the above study, we can draw the following main conclusions:

1. Our crystallographic results on synthetic stepanovite and zhemchuzhnikovite provide unequivocal evidence that the natural minerals possess the same crystal and molecular structure as their synthetic counterparts.

2. As a consequence, and after over sixty and fifty years, respectively, since their discovery, we unveil here the structural beauty and complexity of stepanovite and zhemchuzhnikovite and their isotypic relationship with each other and with synthetic $\mathrm{Na}\left[\mathrm{Mg}\left(\mathrm{H}_{2} \mathrm{O}\right)_{6}\right]$ $\left[\mathrm{M}\left(\mathrm{C}_{2} \mathrm{O}_{4}\right)_{3}\right] \cdot 3 \mathrm{H}_{2} \mathrm{O}(\mathrm{M}: \mathrm{Cr}, \mathrm{Al})$ complexes.

3. We confirm the crystal system (trigonal), unit-cell dimensions, and number $Z$ reported for zhemchuzhnikovite mineral, but correct its water content to be a nona-, $\mathrm{Mg}\left[\mathrm{Al}_{x} \mathrm{Fe}_{1-x}\left(\mathrm{C}_{2} \mathrm{O}_{4}\right)_{3}\right] \cdot 9 \mathrm{H}_{2} \mathrm{O}$, rather than an octa-hydrate, an error that permeates most referencing. Also, we found a close structural relationship of our synthetic stepanovite with the scarce crystallographic data published for the natural sample. Furthermore, we determined the correct space group for these minerals 
to be $P 3 c 1$ and succeeded in a full crystal-structure determination. The nine water molecules nicely split into two sets. One of them contains six water molecules coordinated to magnesium. The other set contains the remaining three molecules which act as hydrogenbonded water molecules.

4. The crystals are arranged as honeycomb-like layers perpendicular to the trigonal $c$-axis. These layers can be conveniently described as $\mathrm{Na}\left[\mathrm{Mg}\left(\mathrm{H}_{2} \mathrm{O}\right)_{6}\right]$ $\left[\mathrm{M}\left(\mathrm{C}_{2} \mathrm{O}_{4}\right)_{3}\right], \mathrm{M}=\mathrm{Fe}, \mathrm{Al} / \mathrm{Fe}$, and the whole crystal as $\mathrm{Na}\left[\mathrm{Mg}\left(\mathrm{H}_{2} \mathrm{O}\right)_{6}\right]\left[\mathrm{M}\left(\mathrm{C}_{2} \mathrm{O}_{4}\right)_{3}\right] .3 \mathrm{H}_{2} \mathrm{O}$. Neighboring layers are $c / 2$ apart and weakly bonded to each other mainly through $\mathrm{H}$-bonding bridges involving the three hydrogen-bonded water molecules.

5. Also from the vibrational spectroscopic point of view, both synthetic minerals are fully comparable, as expected for a pair of isotypic compounds. Their IR spectra also compare very well with that of a natural sample of the mineral zhemchuzhnikovite and are also very close to those of the isotypic complexes $\mathrm{Na}\left[\mathrm{Mg}\left(\mathrm{H}_{2} \mathrm{O}\right)_{6}\right]\left[\mathrm{M}\left(\mathrm{C}_{2} \mathrm{O}_{4}\right)_{3}\right] \cdot 3 \mathrm{H}_{2} \mathrm{O}(\mathrm{M}=\mathrm{Cr}, \mathrm{Al})$.

Acknowledgments We would like to thank Dr. Takuya Echigo and Dr. Uwe Kolitsch for their thorough revisions that helped to improve our article. This work was supported by the Universidad Nacional de La Plata, by CONICET (PIP 1529) and by ANPCyT (PME06 2804 and PICT06 2315) of Argentina. OEP, GAE and AGB are research fellows of CONICET.

\section{References}

Anthony JW, Bideaux RA, Bladh KW, Nichols MC (eds) (2004) Handbook of mineralogy, mineralogical society of America, Chantilly, VA 20151-1110, USA; http://www.handbookofmineralogy.org/

Atencio D, Coutinho JMV, Graeser S, Matioli PA, Menezes Filho LAD (2004) Lindbergite, a new Mn oxalate dihydrate from Boca Rica mine, Galiléia, Minas Gerais, Brazil, and other occurrences. Am Mineral 89:1087-1091

Baran EJ (1995) Química bioinorgánica. McGraw-Hill Interamericana de España SA, Madrid

Baran EJ (2014) Review: natural oxalates and their analogous synthetic complexes. J Coord Chem 23-24:3734-3768

Baran EJ, Monje PV (2009) Oxalate biominerals. In: Sigel A, Sigel H, Sigel RKO (eds) Metal ions in life sciences, vol 4., Biomineralization, from nature to applicationsWiley, Chichester, pp 219-254

Chukanov NV (2014) Infrared spectra of mineral species, vol 1. Springer, Dordrecht

Chukanov NV, Pekov IV, Olysych LV, Massa W, Yakubovich OV, Zadov AE, Rastsvetaeva RK, Vigasina MF (2010) Kyanoxalite, a new cancrinite group mineral species with extraframework oxalate anion from the Lovezaro Alkaline Pluton, Kola Peninsula. Geol Ore Deposits 52:778-790

Clarke RM, Williams IR (1986) Moolooite, a naturally occurring hydrated copper oxalate from Western Australia. Mineral Mag 50:295-298

CrysAlisPro (2014) Oxford diffraction Ltd., Version 1.171.37.31 (release 14-01-2014 CrysAlis171.NET)
Echigo T, Kimata M (2010) Crystal chemistry and genesis of organic minerals: a review of oxalate and polycyclic aromatic hydrocarbon minerals. Canad Mineral 48:1329-1357

Edwards HGM, Russell NC (1998) Vibrational spectroscopic study of iron(II) and iron(III) oxalates. J Mol Struc 443:223-231

Farrugia LJ (1997) ORTPEP-3 for Windows-A version of ORTEP-III with a graphical user interface (GUI). J Appl Crystallogr 30:565

Fleischer M (1955) New mineral names: stepanovite. Am Mineral 40:551

Fleischer M (1956) New mineral names: minguzzite. Am Mineral 41:370

Fleischer M (1962) New mineral names: Zhemchuzhnikovite. Am Mineral 47:1482-1483

Fleischer M (1964) New mineral names: zhemchuzhnikovite, Stepanovite. Am Mineral 49:442

Fraústo da Silva JJR, Williams RJP (1991) The biological chemistry of the elements. Clarendon Press, Oxford

Frossard L (1956) Etude de trioxalatochrominate de sodium et de magnésium. Schweiz Mineral Petrograph Mitt 36:1-25

Fujita J, Martell AE, Nakamoto K (1962a) Infrared spectra of metal chelate compounds. VI. A normal coordinate treatment of oxalate metal complexes. J Chem Phys 36:324-331

Fujita J, Martell AE, Nakamoto K (1962b) Infrared spectra of metal chelate compounds. VII. Normal coordinate treatments on 1:2 and 1:3 oxalato complexes. J Chem Phys 36:331-338

Garavelli CL (1955a) Ritrovamento de oxalite tra i minerali secondari del giacimento de Capo Calamita. Rend Soc Mineral Ital 11:176-181

Garavelli CL (1955b) Un nuovo minerali tra i prodotti secondari del giacimento di Capo Calamita (Isola d'Elba). Atti Accad Naz Linzei 18:392-402

Junk PC (2005) Supramolecular interactions in the X-ray crystal structure of potassium tris(oxalato)ferrate(III) trihydrate. J Coord Chem 58:355-361

Khan SR (1995) Calcium oxalate in biological systems. CRC Press, Boca Raton

Knipovich YN, Komkov AI, Nefedov EI (1963) On stepanovite and the new mineral zhemchuzhnikovite. Trudy Vses Nauchno-Issled Geol Inst 96:131-135 (in Russian)

Krishnamurty KY, Harris GM (1961) The chemistry of the metal oxalate complexes. Chem Rev 61:213-246

Libowitzky E (1999) Correlation of O-H stretching frequencies and $\mathrm{O}-\mathrm{H} \cdots \mathrm{O}$ hydrogen bond lengths in minerals. Monatsh Chem 130:1047-1059

Lipkowski J, Herbich J (1975) Preparation, composition and crystal growth of sodium magnesium tris(oxalato)aluminate nonahydrate containing ferric ions. Rocz Chem 49:853-857 (in Polish)

Matioli PA, Atencio DM, Coutinho JMV, Menezes Filho LAD (1997) Humboldtina de Santa Maria de Itabira, Minas Gerais, primeira ocorrência brasileira e primeira ocorrência mundial em fraturas de pegmatito. Anais Acad Bras Cien 69:431-432

Monje PV, Baran EJ (2004) Plant biomineralization. In: Hemantaranjan A (ed) Advances in plant physiology, vol 7. Scientific Publishers, Jodhpur, pp 395-410

Mortensen OS (1967) Vibronic spectra of transition-metal complexes. I. Polarized emission and absorption spectra of $\mathrm{NaMg}\left[\mathrm{Cr}\left(\mathrm{C}_{2} \mathrm{O}_{4}\right)_{3}\right] \cdot 9 \mathrm{H}_{2} \mathrm{O}$. J Chem Phys 47:4215-4222

Nakamoto K (2009) Infrared and Raman spectra of inorganic and coordination compounds, 6th edn. Wiley, New York

Nefedov EI (1953) Report of new minerals discovered by him. Zapisky Vses Mineral Obshch 82:311-317 (in Russian)

Peacor DR, Rouse RC, Essene EJ, Lauf RJ (1999) Coskrenite-(Ce) $(\mathrm{Ce}, \mathrm{Nd}, \mathrm{La})_{2}\left(\mathrm{SO}_{4}\right)_{2}\left(\mathrm{C}_{2} \mathrm{O}_{4}\right) \cdot 8 \mathrm{H}_{2} \mathrm{O}$, a new rare earth oxalate mineral from Alum Cave Bluff, Tennessee: characterization and crystal structure. Canad Mineral 37:1453-1462 
Piper TS, Carlin RL (1960) Polarized visible spectra of crystalline trisoxalato-metallates: the source of intensity. J Chem Phys 33:608-609

Piper TS, Carlin RL (1961) Polarized visible spectra of crystalline trisoxalato-metallates. J Chem Phys 35:1809-1815

Piro OE, Echeverría GA, González-Baró AC, Baran EJ (2015) Crystallographic new light of an old complex: $\mathrm{NaMg}\left[\mathrm{Cr}\left(\mathrm{C}_{2} \mathrm{O}_{4}\right)_{3}\right] \cdot 9 \mathrm{H}_{2} \mathrm{O}$ and structure redetermination of the isomorphous aluminum(III) compound. J Coord Chem 38:3776-3787

Riesen H, Rae D (2008) Revisiting the crystal structure and thermal properties of $\mathrm{NaMgAl}$ (oxalate) $)_{3} \cdot 9 \mathrm{H}_{2} \mathrm{O} / \mathrm{Cr}$ (III): an extraordinary spectral hole-burning material. Dalton Trans 2008:4717-4722

Rouse RC, Peacor DR, Dunn PJ, Simmons WB, Newbury D (1986) Wheatleyite, $\mathrm{Na}_{2}\left[\mathrm{Cu}\left(\mathrm{C}_{2} \mathrm{O}_{4}\right)_{2}\right] \cdot 2 \mathrm{H}_{2} \mathrm{O}$, a natural sodium copper salt of oxalic acid. Am Mineral 71:1240-1242

Rouse RC, Peacor DR, Essene EJ, Coskren TD, Lauf RJ (2001) The new minerals levinsonite- $(\mathrm{Y})\left[(\mathrm{Y}, \mathrm{Nd}, \mathrm{Ce}) \mathrm{Al}\left(\mathrm{SO}_{4}\right)_{2}\left(\mathrm{C}_{2} \mathrm{O}_{4}\right) \cdot 12 \mathrm{H}_{2} \mathrm{O}\right]$ and zugshunstite-(Ce) [(Ce, Nd, $\left.\mathrm{La}) \mathrm{Al}\left(\mathrm{SO}_{4}\right)_{2}\left(\mathrm{C}_{2} \mathrm{O}_{4}\right) \cdot 12 \mathrm{H}_{2} \mathrm{O}\right]$ : coexisting oxalates with different structures and differentiation of LREE and HREE. Geochim Cosmochim Acta 65:1101-1115

Saritha A, Raju B, Ramachary M, Raghavaiah P, Hussain KA (2012) Synthesis, crystal structure and characterization of chiral, threedimensional anhydrous potassium tris(oxalato)ferrate(III). Phys B 407:4208-4213

Sheldrick GM (2008) A short history of SHELX. Acta Crystallogr A 64:112-122

Sheldrick GM (2015) SHELXT-Integrated space group and crystal structure determination. Acta Crystallogr A 71:3-8
Siebert H (1966) Anwendungen der Schwingungsspektroskopie in der Anorganischen Chemie. Springer, Berlin

Strunz H, Nickel EH (2001) Strunz Mineralogical Tables. E. Schweizerbart'sche Verlagsbuchhandlung, Stuttgart

Suh J-S, Shin J-Y, Yoon C, Lee K-W, Suh I-H, Lee J-H, Ryu B-Y, Lim S-S (1994) The crystal and molecular structure of sodium magnesium tris(oxalate) chromate(III) decahydrate, $\mathrm{NaMg}\left[\mathrm{Cr}\left(\mathrm{C}_{2} \mathrm{O}_{4}\right)_{3}\right] \cdot 10 \mathrm{H}_{2} \mathrm{O}$. Bull Kor Chem Soc 15:245-249

Taylor D (1978) The crystal structures of potassium tris(oxalato)chromate(III) and -aluminate(III) trihydrate: a reinvestigation. Austral J Chem 31:1455-1462

Truchanowicz T (1974) Thermal analysis and determination of x-ray powder data for sodium magnesium trioxalatoaluminate nonahydrate and sodium magnesium trioxalatochromate(III) nonahydrate crystals. Chem Anal (Warsaw) 19:1089-1094 (in Polish)

Truchanowicz T, Durski Z (1971) Determination of lattice constants and possible space groups of $\mathrm{NaMg}\left[\mathrm{Al}\left(\mathrm{C}_{2} \mathrm{O}_{4}\right)_{3}\right] \cdot 9 \mathrm{H}_{2} \mathrm{O}$ crystals. Rocz Chem 45:1777-1778 (in Polish)

van Niekerk JN, Schoening FRL (1952) The structure of potassium trioxalatochromate(III), $\mathrm{K}_{3}\left[\mathrm{Cr}\left(\mathrm{C}_{2} \mathrm{O}_{4}\right)_{3}\right] \cdot 3 \mathrm{H}_{2} \mathrm{O}$. Acta Crystallogr 5:196-202

Weiner S, Dove PM (2003) An overview of biomineralization processes and the problem of the vital effect. In: Dove PM, De Yoreo JJ, Weiner S (eds) Reviews in mineralogy and geochemistry, vol 54., Mineralogical SocAmerica/Geochemical Soc, Washington, DC, pp 1-29 